\title{
GLAVNI PROJEKT TRGOVAČKOG CENTRA „PORTANOVA“ U OSIJEKU: BETONSKI DIJELOVI GRAĐEVINE
}

\author{
Ivan Ivandić \\ Sveučilište u Splitu, Građevinsko-arhitektonski fakultet Split, student \\ Tomislav Lovrić \\ Sveučilište u Splitu, Građevinsko-arhitektonski fakultet Split, student \\ Alen Harapin \\ Sveučilište u Splitu, Građevinsko-arhitektonski fakultet Split, prof.dr.sc.
}

Sažetak: U radu je prikazan dio projekta konstrukcije trgovačkog centra Portanova u Osijeku. Cijela građevina obrađena je kroz nekoliko diplomskih radova koji zajedno sačinjavaju jednu cjelinu. U ovom članku prikazan je koncept cjelokupne konstrukcije i proračun betonskih dijelova građevine. Tlocrtna površina građevine je oko 24.000 $\mathrm{m}^{2}$ (cca 285x80 m), a ukupna bruto površina oko $79.000 \mathrm{~m}^{2}$. Građevina se sastoji od jedne podzemne i tri nadzemne etaže. Podrum je u potpunosti izveden u armiranom betonu, a katovi su spregnuta konstrukcija čelični nosači oslonjeni na betonske stupove. Projektni zahtjev je opterećenje od $10.0 \mathrm{kN} / \mathrm{m}^{2}$ na ploči prizemlja - na mjestu Supermarketa i $5.0 \mathrm{kN} / \mathrm{m}^{2}$ na ostalom dijelu. Građevina se nalazi na lokaciji koja prema važećim propisima spada u VIII seizmičku zonu i I vjetrovnu zonu.

Ključne riječi: trgovački centar, glavni projekt konstrukcije

\section{MAIN DESIGN OF SHOPPING CENTER „PORTANOVA“ IN OSIJEK: CONCRETE PARTS OF THE BUILDING}

\begin{abstract}
The paper presents structural system of the shopping mall Portanova in Osijek. The whole building was treated through a few theses that together constitute a complete work. This section presents the concept of structure and calculation of concrete parts of the building. Layout area of the building is approximately $24.000 \mathrm{~m}^{2}$ (about $285 \times 80 \mathrm{~m}$ ) and a total gross area around $79.000 \mathrm{~m}^{2}$. The building is composed of one underground and three upper ground floors. Basement is fully constructed in reinforced concrete, and the floors are composite structures - steel beams supported on concrete columns. The project request is a load of $10.0 \mathrm{kN} / \mathrm{m}^{2}$ on the board floor - in Supermarket and $5.0 \mathrm{kN} / \mathrm{m}^{2}$ in other parts. The building is located in the VIII seismic zone and I wind zone.
\end{abstract}

Key words: shopping mall, main design of structure 


\section{Uvod}

U radu je ukratko prikazan konstrukcijski sustav te detalji projektiranja i izvođenja trgovačkog centra Portanova u Osijeku. Tlocrtna površina građevine je oko $24.000 \mathrm{~m}^{2}$, a ukupna korisna površina oko $50.000 \mathrm{~m}^{2}$. Trgovački centar Portanova se visinski sastoji od jedne podzemne i tri nadzemne etaže. U podrumu zgrade projektirana je garaža, tehničke prostorije i spremišta. Nadzemne etaže predviđene su za razne trgovačke sadržaje, kino dvorane i sadržaje ugostiteljske namjene i zabavnog karaktera. Na dijelu drugog kata (krov 1. kata) projektirano je otvoreno parkiralište. Građevina se, u konstrukcijskom smislu, sastoji od 4 dilatacije koje su konstrukcijski potpuno odvojene, a nalaze se na zajedničkoj temeljnoj ploči. Dilatacije 1 i 2 su dvoetažne (garaža + dvije nadzemne etaže), dilatacija 3 je dijelom dvoetažna a dijelom troetažna, a dilatacija 4 je troetažna (garaža + tri nadzemne etaže) (slike 3, 5, 6, 7).

Podna ploča je armiranobetonska ploča, debljine $80 \mathrm{~cm}$. Ova ploča je uglavnom neprekinuta, osim na mjestima početka travelatora/eskalatora gdje je izvedeno udubljenje od $1.1 \mathrm{~m}$ i na mjestima liftova gdje je izvedeno udubljenje od $1.5 \mathrm{~m}$. Ploča je armirana šipkastom armaturom u obje zone. Debljina ploče služi ujednačavanju opterećenja na temeljnom tlu i eliminaciji mogućeg diferencijalnog slijeganja.

Konstrukcija ploče garaže je armiranobetonska monolitna konstrukcija koja se sastoji od armiranobetonskih ploča $(\mathrm{d}=22 \mathrm{~cm}$ ) koje su povezane gredama $65 \times 60 \mathrm{~cm}$ (smjer sjever-jug) i $60 \times 60 \mathrm{~cm}$ (smjer istok-zapad). Na pojedinim mjestima izvedena je greda dimenzija $60 / 80 \mathrm{~cm}$ na koju se naslanjaju stupovi. Garaža je u djelomično ukopana i kao takva ukrućena obodnim zidovima i nasipom zemlje za horizontalna opterećenja. Usto, tlocrtna površina ima relativno jednoliko raspodijeljene jezgre (stubišta, liftovi, travelator). Vertikalni nosivi sustav su stupovi dimenzija 90x60 (na mjestima gdje se oni nastavljaju u prizemlju), tj. stupovi dimenzija $60 \times 60 \mathrm{~cm}$ (na mjestima gdje završavaju na nivou prizemlja). Osim ovih stupova, na pojedinim mjestima su izvedeni stupovi 40x40 koji pridržavaju fasadu.

Za osnovni raster objekta na etažama predviđen je raster $16.20 \times 8.10 \mathrm{~m}$ (svaki drugi stup iz garaže se ukida u smjeru sjever-jug). Kao međukatna konstrukcija predviđena je spregnuta konstrukcija čelik - beton (predmet drugog diplomskog rada).

Materijal izrade je beton kvalitete $C$ 30/37. Projektni zahtjev je opterećenje od $10.0 \mathrm{kN} / \mathrm{m}^{2}$ na ploči prizemlja na mjestu Supermarketa i $5.0 \mathrm{kN} / \mathrm{m}^{2}$ na ostalom dijelu. Građevina se nalazi na lokaciji koja prema važećim propisima spada u VIII seizmičku zonu i I vjetrovnu zonu.

Sudionici u građenju su:

- investitor:

- koordinator projekta:

- autori koncepta:

- glavni projektant:

Amplitudo d.o.o. Osijek

Mace d.o.o., Beograd

Chapman Taylor Achitetti, Milano

Studio XXL, Zagreb

- projektant konstrukcije: Aspalathosoft d.0.o. Split

- glavni izvođač radova: Gradnja d.o.o. Osijek

- nadzor:

Zavod za urbanizam i izgradnju d.d., Osijek.

\section{Smještaj građevine}

Građevina je smještena na jugozapadnom dijelu prostora Retfala-jug u Osijeku, na zemljištu površine cca $50.000,00 \mathrm{~m}^{2}$. Zemljište se nalazi na području Urbanističkog plana uređenja područja između južne obilaznice i željezničke pruge u Osijeku, „Retfala - jug“ - I. etapa zapadni dio (slika 1). Zemljǐste ima poslovno gospodarsku namjenu. Građevinska parcela poslovno trgovačkog centra formirana je na parceli 9463/1 k.0. Osijek. Novoformirana parcela je gotovo pravokutnog oblika, izduženog u smjeru istok-zapad. S južne strane parcele proteže se brza prometnica - južna obilaznica, sa zapadne strane odvojak s južne obilaznice (slika 2). Sjevernom $\mathrm{i}$ istočnom međom parcela graniči s prometnicama u izgradnji prema Urbanističkom planu. Tlocrtna površina građevine je oko $24.000 \mathrm{~m}^{2}$ (cca 285x80 m), a ukupna bruto površina oko $79.000 \mathrm{~m}^{2}$. 


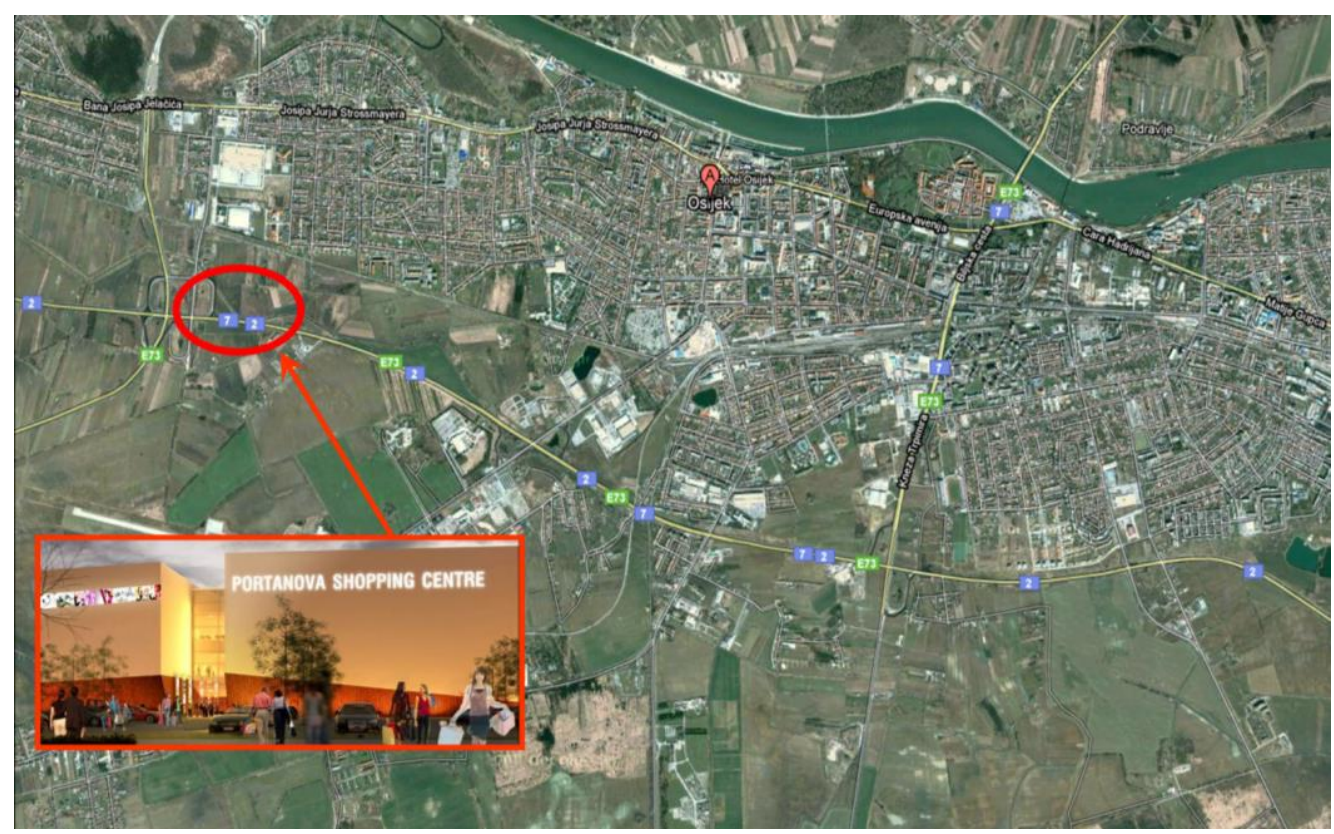

Slika 1 - Geografski položaj građevine

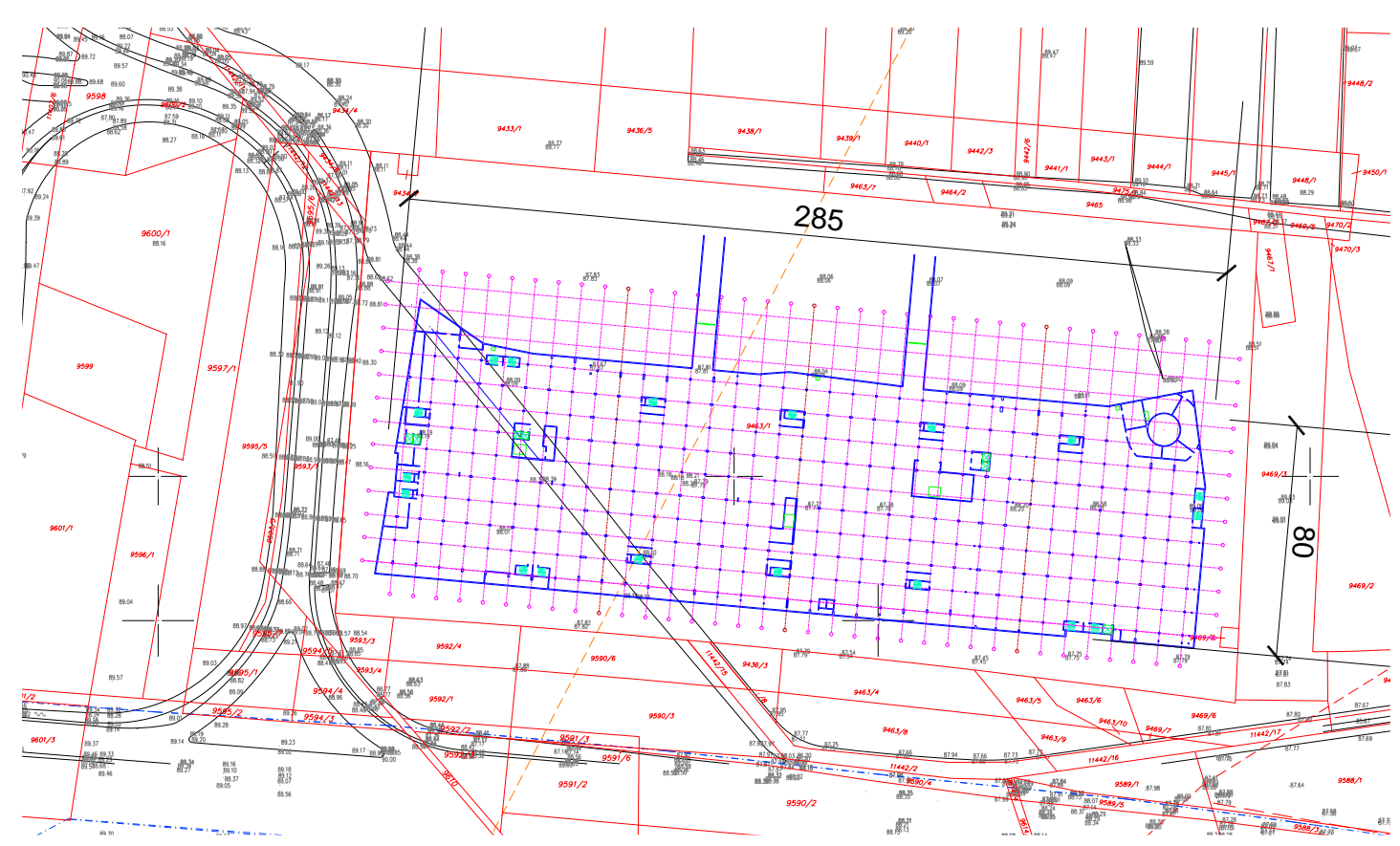

Slika 2 - Položaj građevine na situacijskom nacrtu i orijentacijske dimenzije građevine

\section{Izgled i oblik građevine}

Centar se visinski sastoji od jedne podzemne i tri nadzemne etaže. U podrumu zgrade projektirana je garaža, tehničke prostorije i spremišta. Nadzemne etaže predviđene su za razne trgovačke sadržaje, kino dvorane i sadržaje ugostiteljske namjene i zabavnog karaktera. Na dijelu drugog kata (krov 1. kata) projektirano je otvoreno parkiralište (slika 3). 


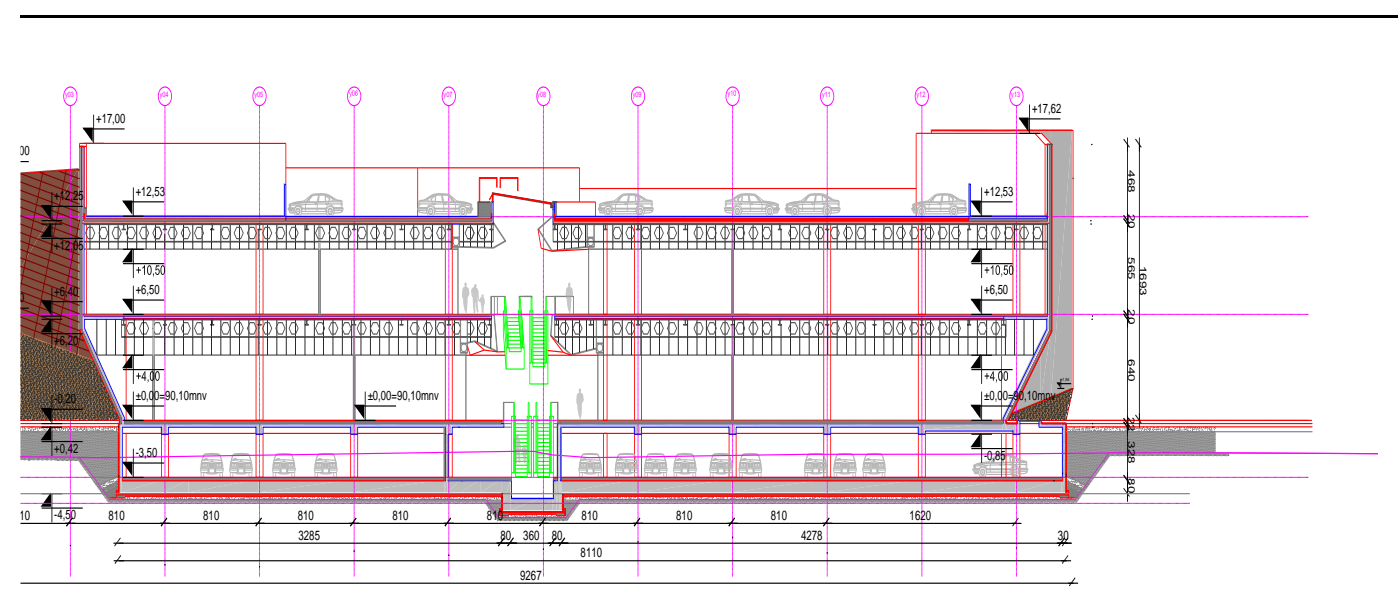

\section{Slika 3 - Poprečni presjek trgovačkog centra}

Građevina se, u konstrukcijskom smislu, sastoji od 4 dilatacijske jedinice koje su konstrukcijski potpuno odvojene, a nalaze se na zajedničkoj temeljnoj ploči (slika 4). Dilatacije 1 i 2 su dvoetažne (podrum + dvije nadzemne etaže), dilatacija 3 je dijelom dvoetažna a dijelom troetažna, a dilatacija 4 je troetažna (podrum + tri nadzemne etaže).

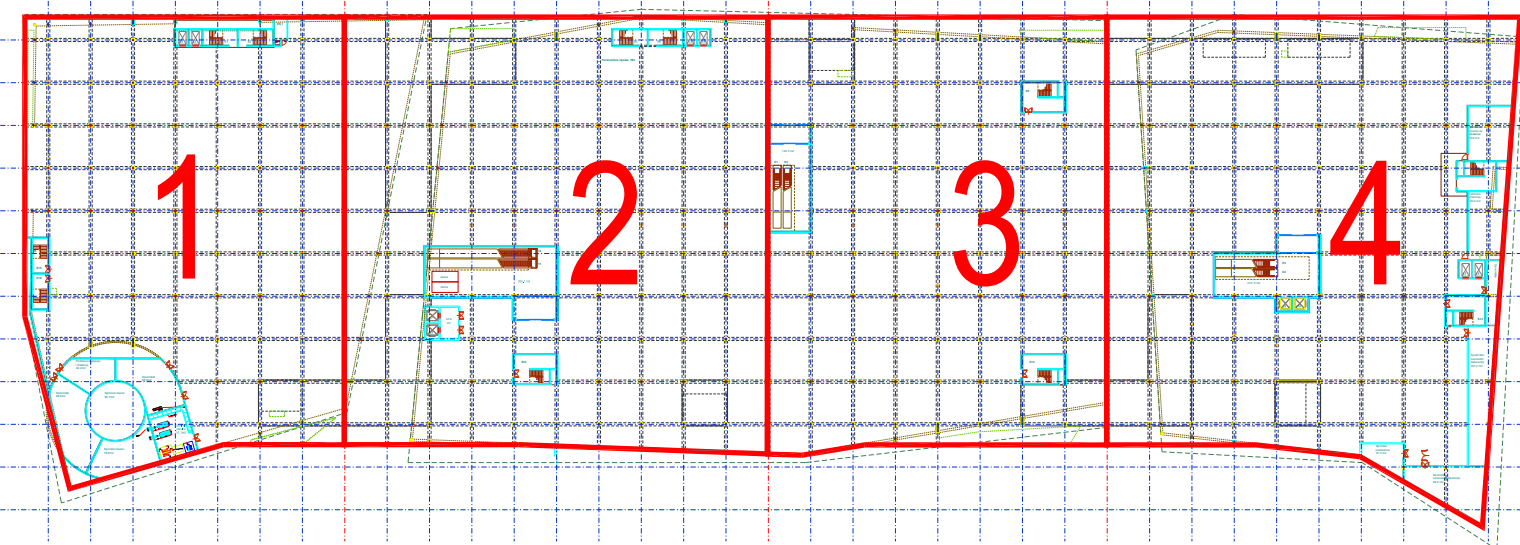

Slika 4 - Prikaz dilatacijskih jedinica 
U podrumskom dijelu se nalazi garaža (slika 5).

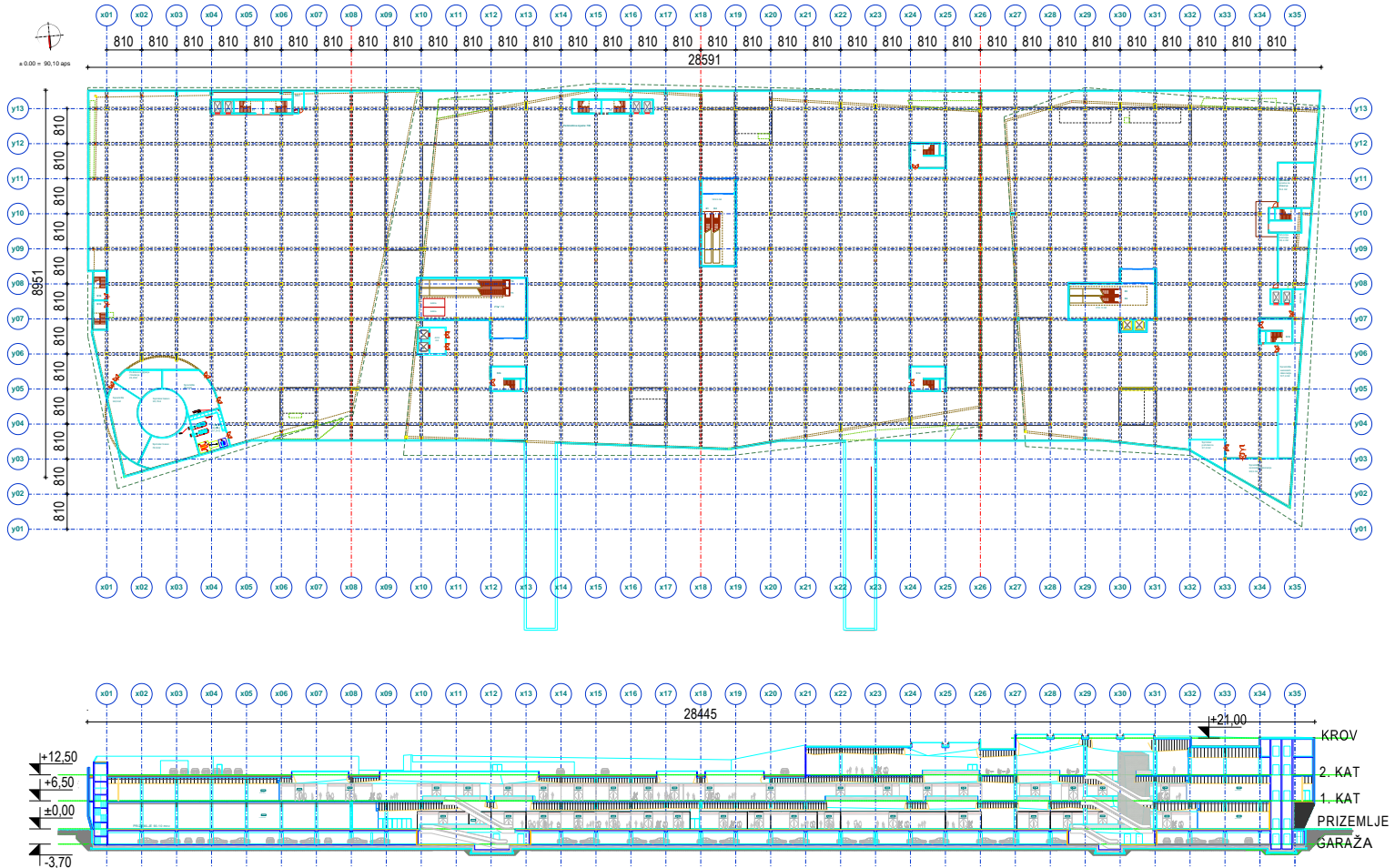

\section{Slika 5 - Tlocrt podruma i uzdužni presjek}

U prizemlju se nalazi supermarket i trgovački sadržaji (slika 6).

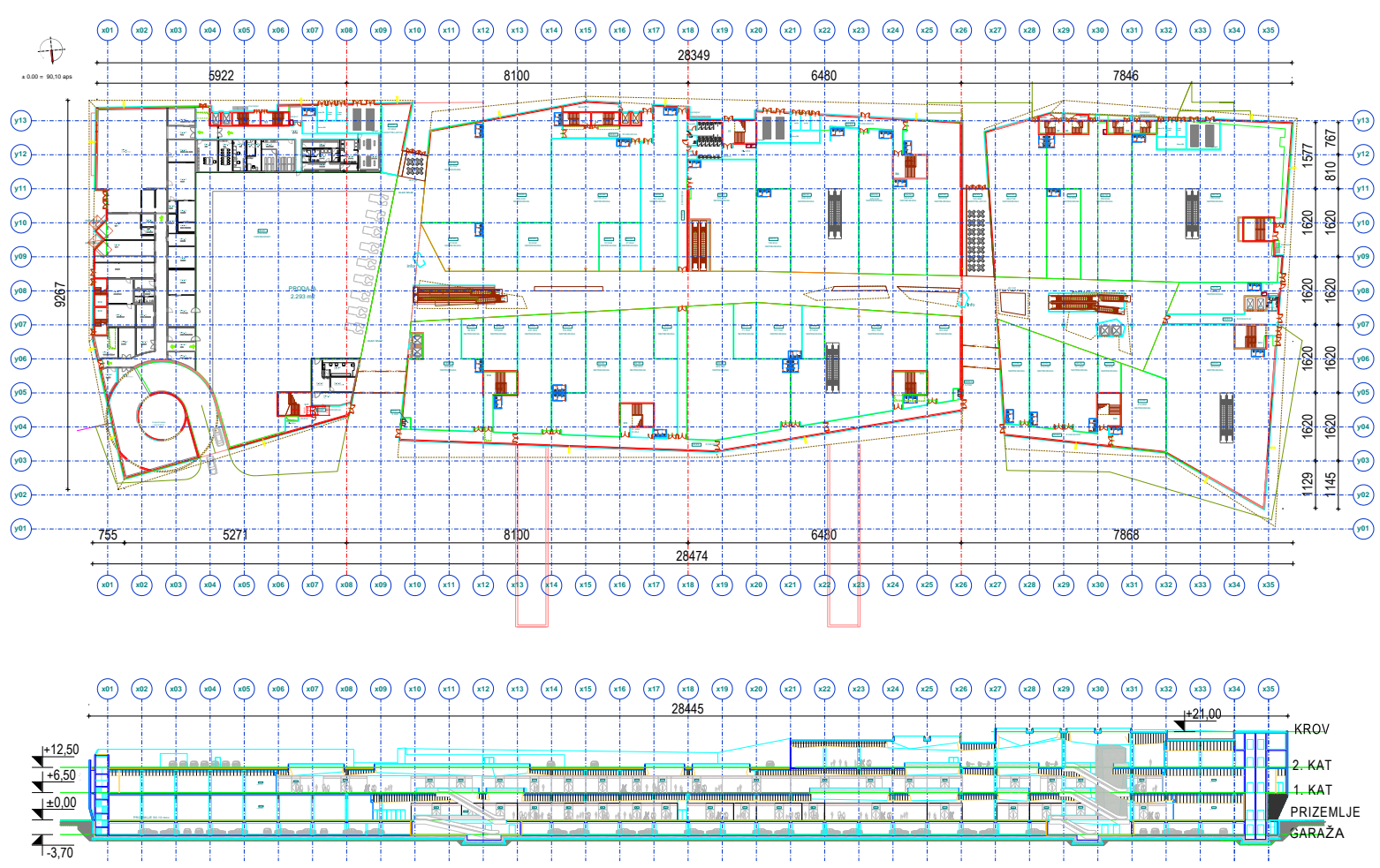

Slika 6 - Tlocrt prizemlja i uzdužni presjek 
Na 1. katu se nalaze trgovački sadržaji (slika 7).

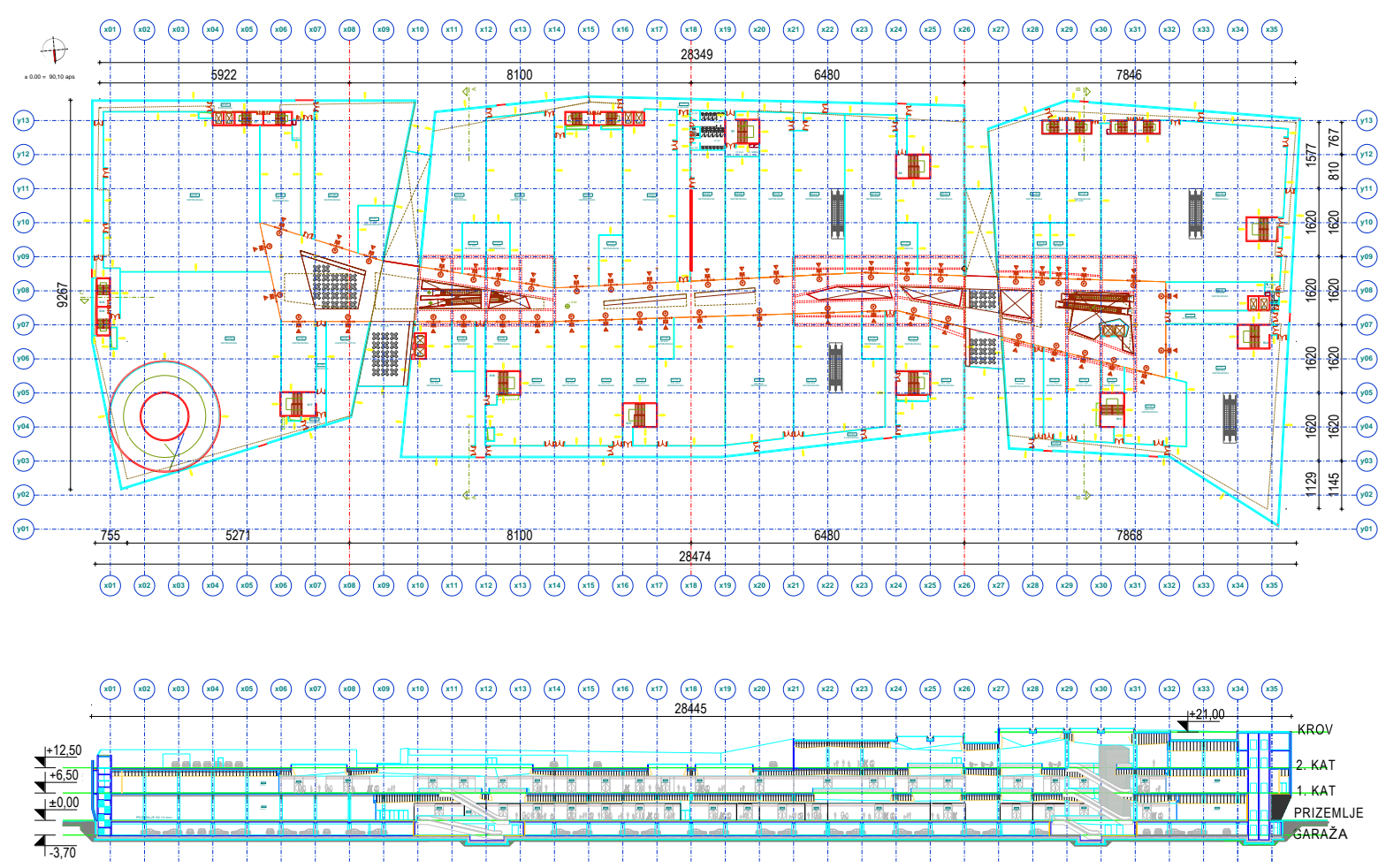

\section{Slika 7 - Tlocrt 1. kata i uzdužni presjek}

Na 2. katu se nalaze zabavni sadržaji: kino dvorane, ugostiteljski lokali, a na dijelu kata je parkiralište (slika 8).

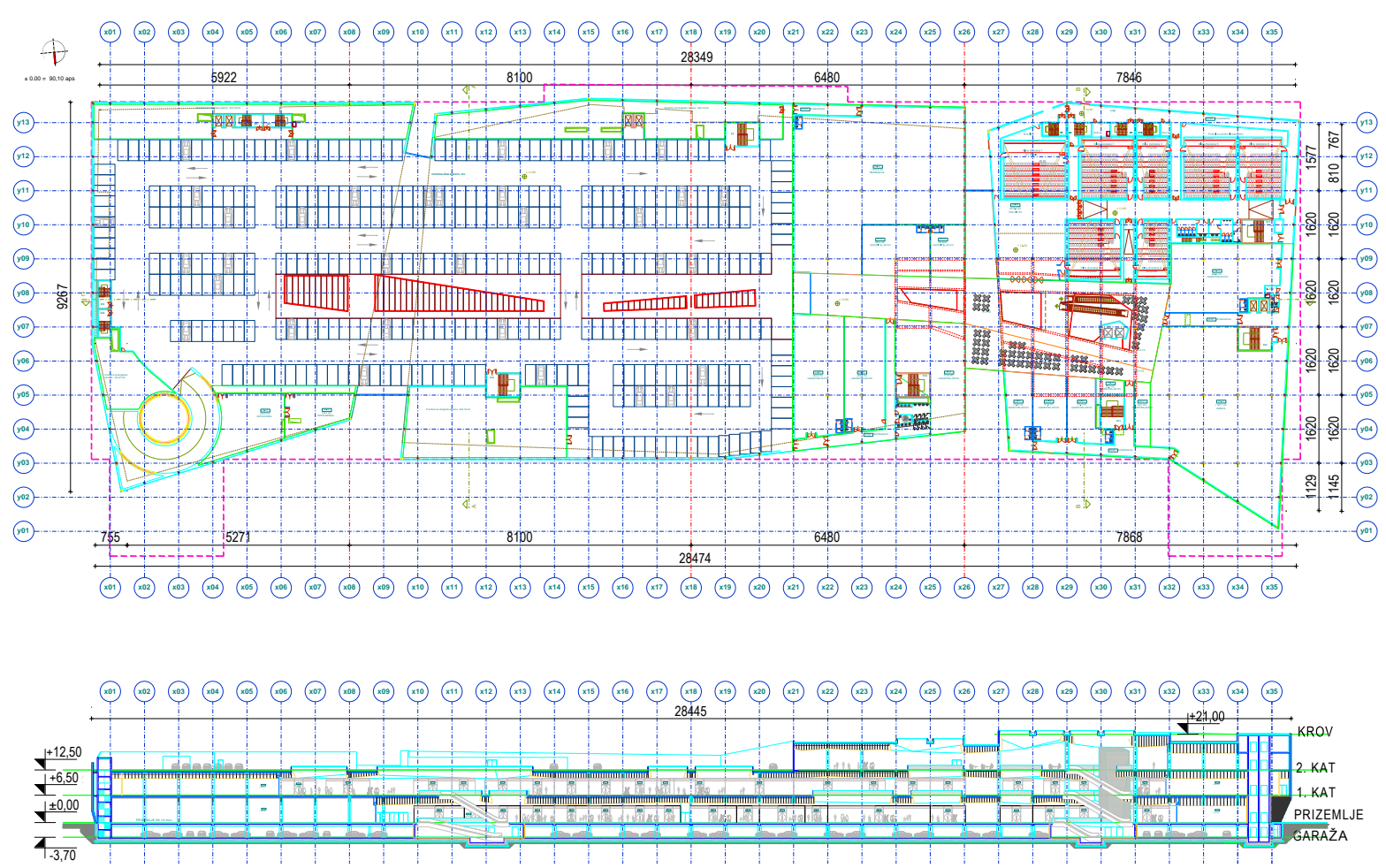

Slika 8 - Tlocrt 2. kata i uzdužni presjek 


\section{Koncept}

Idejno arhitektonsko rješenje odraz je prirode i lokalnog okruženja. Građevina je zamišljena u obliku tri velike stijene koje se odmaraju na tlu. Iskrivljenost fasadnih ploha i nepravilnost (razvedenost) tlocrta doveli su do odabranog konstrukcijskog rješenja - spregnute konstrukcije (slika 9).
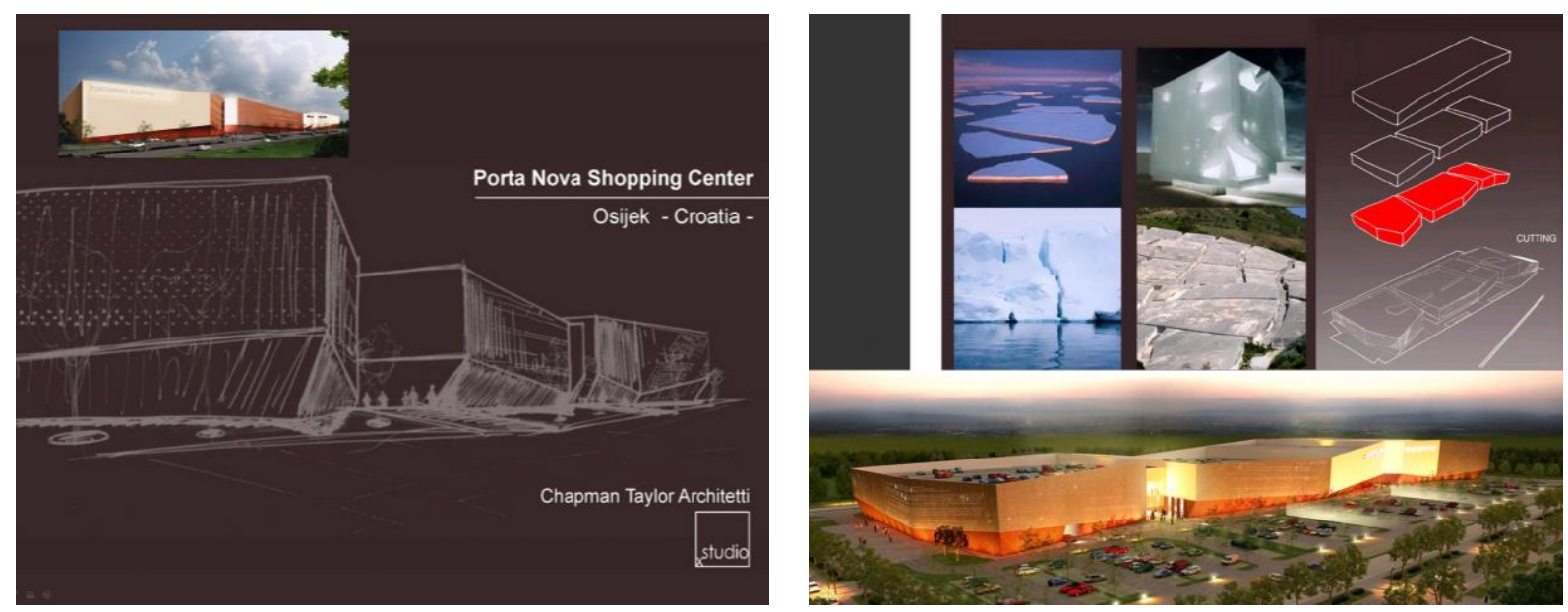

\section{Slika 9 - Neka razmišljanja pri odabiru arhitektonskog koncepta građevine}

Kao konstrukcijsko rješenje odabrana je monolitna betonska konstrukcija u podrumu i spregnuta konstrukcija na katovima. Ovo rješenje prikazano je na numeričkom modelu za dilataciju 2. Konstrukcija podruma je relativno pravilna: ab ploča oslonjena na sustav ab greda u oba smjera (slika 10-b). Konstrukcija 1. kata je također uglavnom pravilna (raster 16.2x8.1), a ispresijecana je kosim mall-ovima (slika 10-c). Na 2. katu nastavlja se tlocrt 1. kata - uglavnom pravilna konstrukcija ispresijecana kosim mall-ovima (slika 10-d).

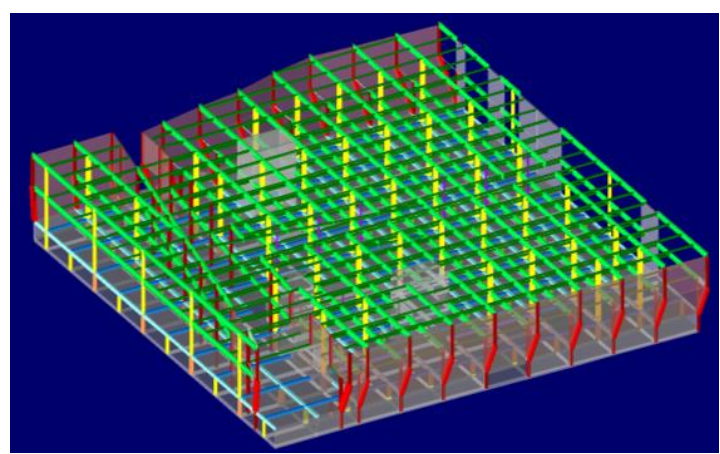

(a) Cijela dilatacijska jedinica

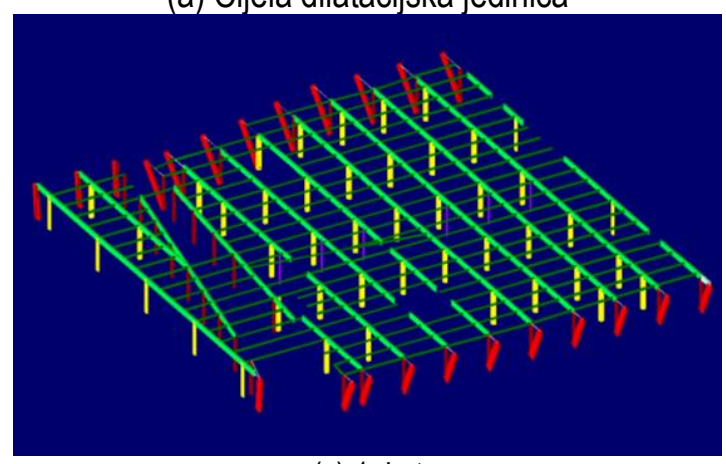

(c) 1. kat

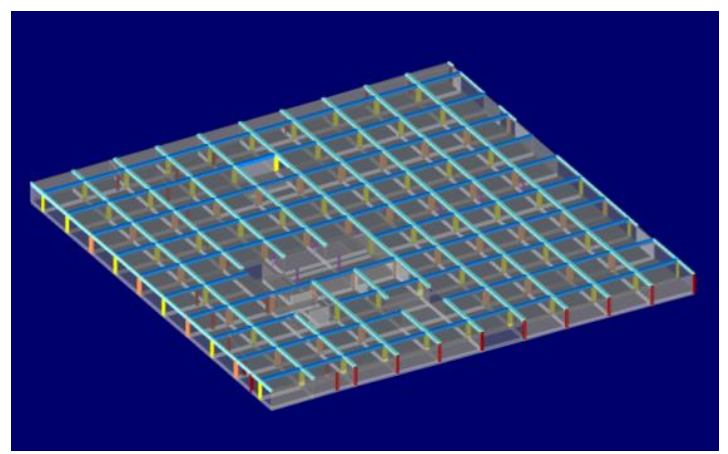

(b) Podrum

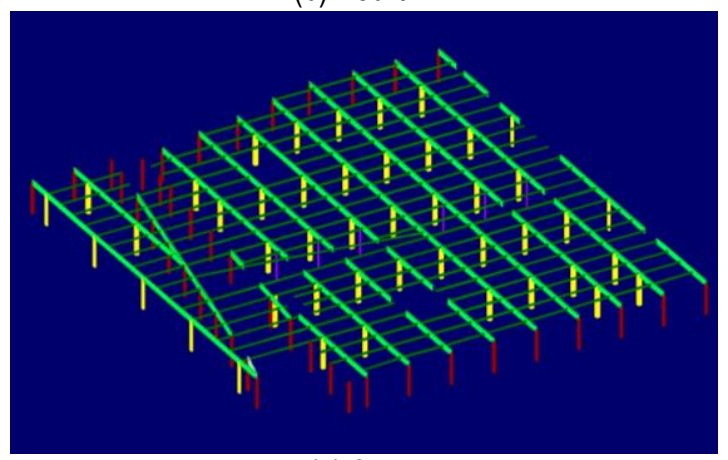

(d) 2. kat

Slika 10 - Dilatacija D2 - potpuni render i render konstrukcijskih elemenata po katovima 


\section{Materijali}

Za izgradnju betonskog dijela građevine koristi se beton projektiranog sastava, razreda tlačne čvrstoće normalnog betona C 30/37, a sve prema "Tehničkim propisima za betonske konstrukcije" (NN 101/05; 74/06; 85/06; 64/07). Tehnički uvjeti za projektirana svojstva svježeg betona dani su u tablici 1.

Kao armatura koristi se betonski čelik B 500 (tip B, prema TPBK) za sve elemente, u obliku šipki ili mreža. Zaštitni slojevi betona do armature iznose $2.0-5.0 \mathrm{~cm}$.

\section{Tablica 1 - Svojstva svježeg i očvrslog betona}

\begin{tabular}{|c|c|c|c|c|c|c|}
\hline \multicolumn{2}{|l|}{ NAMJENA } & Podbeton & $\begin{array}{l}\text { Temeljna ploča, } \\
\text { šahte liftova i } \\
\text { elevatora u tlu }\end{array}$ & $\begin{array}{l}\text { Ploča nad garažom, } \\
\text { unutarnji zidovi, } \\
\text { grede, stubišta i } \\
\text { veći stupovi } \\
\left(\geq 0.12 \mathrm{~m}^{3}\right. \\
\left.\text { betona } / \mathrm{m}^{2} \mathrm{ili} \mathrm{m}^{\prime}\right)\end{array}$ & $\begin{array}{c}\text { Stupovi, ploče } \\
\text { spregnute } \\
\text { konstrukcije i ostali } \\
\text { konstrukcijski } \\
\text { elementi malog } \\
\text { presjeka } \\
\left(\leq 0.12 \mathrm{~m}^{3} \text { betona/ }\right. \\
\left.\mathrm{m}^{2} \mathrm{ili} \mathrm{m}^{\prime}\right) \\
\end{array}$ & $\begin{array}{c}\text { Ploča garaže } \\
\text { na krovu, } \\
\text { vanjski zidovi } \\
\text { podruma }\end{array}$ \\
\hline \multicolumn{7}{|c|}{ TRAŽENA SVOJSTVA SVJEŽEG I OČVRSLOG BETONA } \\
\hline \multicolumn{2}{|l|}{ Klasa } & A & B & C & $\mathrm{D}$ & $\mathrm{E}$ \\
\hline \multicolumn{2}{|c|}{ razred čvrstoće normalnog betona } & C 16/20 & \multicolumn{4}{|c|}{ C $30 / 37$} \\
\hline \multicolumn{2}{|c|}{ razred izloženosti } & $\mathrm{X} 0$ & \multicolumn{3}{|c|}{$\mathrm{XC3}$} & $\mathrm{XD2}{ }^{*}$ \\
\hline minimalna količina cementa & $\left(\mathrm{kg} / \mathrm{m}^{3}\right)$ & 260 & \multicolumn{4}{|c|}{360} \\
\hline max. vodocementni faktor & $(\mathrm{v} / \mathrm{c})$ & 0.60 & \multicolumn{4}{|c|}{0.45} \\
\hline \multicolumn{2}{|l|}{ uz dodatak superplastifikatora } & $\mathrm{NE}$ & \multicolumn{4}{|c|}{ DA } \\
\hline razred slijeganja (slump) & razred & S3 ili S4 & \multicolumn{4}{|c|}{ S4 } \\
\hline maksimalno zrno agregata & $(\mathrm{mm})$ & 16 & & 32 & 16 & 32 \\
\hline \multicolumn{2}{|c|}{ zahtjev za vodonepropusnost } & NE & $\mathrm{DA}(\leq 3 \mathrm{~cm})$ & \multicolumn{2}{|c|}{ NE } & $\mathrm{DA}(\leq 3 \mathrm{~cm})$ \\
\hline \multicolumn{2}{|c|}{ zahtjev za nisku hidratacijsku temp. } & NE & DA & \multicolumn{3}{|c|}{$\mathrm{NE}$} \\
\hline \multicolumn{2}{|c|}{ razred sadržaja klorida } & \multicolumn{5}{|c|}{$\mathrm{Cl} 0.20$} \\
\hline min. vrijeme obradivosti & $(\min )$ & 60 & \multicolumn{4}{|c|}{90} \\
\hline temperatura svježeg betona & $\left(+{ }^{\circ} \mathrm{C}\right)$ & \multicolumn{5}{|c|}{$5-30$} \\
\hline
\end{tabular}

* NAPOMENA:

Prema pravilniku (TPBK) i pratećim normama elementi otvorenih garaža i sl. trebali bi pripadati klasi okoliša XD3. Kako je ploča garaže ipak zaštićena slojevima, a s druge strane u širem području predmetne lokacije je vrlo teško proizvesti beton kvalitete veće od C 30/37 u količinama koje traži predmetni objekt, izabran je beton nešto niže kvalitete, uz stroge dodatne zahtjeve (mali vodocementni faktor, vodonepropusnost i sl.).

\section{Analiza opterećenja}

\section{Stalno opterećenje (vlastita težina konstrukcijskih elemenata)}

Uključeno je kroz numerički model.

\section{$\underline{\text { Dodatno stalno opterećenje (težine nekonstrukcijskih elemenata) }}$}

Tablica 2 - Dodatno stalno opterećenje za Supermarket

\begin{tabular}{|c|c|c|c|}
\hline & $d(\mathrm{~m})$ & $\gamma\left(\mathrm{kN} / \mathrm{m}^{3}\right)$ & $d \times \gamma$ \\
\hline \hline Završni sloj poda & 0.025 & 25.0 & 0.60 \\
\hline AB estrih & 0.08 & 25.0 & 2.00 \\
\hline Termoizolacija (prosj. 10.0 cm) & 0.10 & 5.0 & 0.50 \\
\hline Hidroizolacija & 0.02 & 20.0 & 0.40 \\
\hline
\end{tabular}

Ukupno dodatno stalno opterećenje: $\Delta g=3.50\left(\mathrm{kN} / \mathrm{m}^{2}\right)$ 
c) pokretno opterećenje

$\begin{array}{ll}q=10.0\left(\mathrm{kN} / \mathrm{m}^{2}\right) & \text { (Supermarket) } \\ q=5.0\left(\mathrm{kN} / \mathrm{m}^{2}\right) & \text { (ostali prostori) }\end{array}$

Nije vršena kombinacija opterećenja, tj. postavljanje pokretnog opterećenja u najkritičnije položaje, već je pokretno opterećenje uvećano za $20 \%$.

\section{$\underline{\text { Snijeg }}$}

Osijek se nalazi na oko $94 \mathrm{~m}$ n.m. Prema prijedlogu NAD-a i istraživanja opterećenja snijegom na području republike Hrvatske [9], te preporukama europske norme ENV 1991-2-3:1995, uzima se karakteristično opterećenje snijegom (nadmorska visina do $100 \mathrm{~m} \mathrm{n.m.):} \mathrm{s}_{0}=1.10 \mathrm{kN} / \mathrm{m}^{2}$.

\section{Vjetar}

Opterećenje vjetrom odabrano je prema: EC1, Dio 2-4: Djelovanja vjetra i europskoj prednormi ENV 1991-2-4: Djelovanja na konstrukcije opterećenje vjetrom, te Nacionalnom dokumentu za primjenu u Republici Hrvatskoj. Predmetna građevina se nalazi u Osijeku (Osječko-baranjska županija), na poziciji gdje je uglavnom nezaštićena od djelovanja vjetra. Prema navedenim normama, smještena je u I područje djelovanja vjetra te je osnovno djelovanje vjetra:

$$
\begin{aligned}
& \mathrm{V}_{0}=22.0 \mathrm{~m} / \mathrm{s} \\
& C_{\text {dir }}=1.0 \\
& C_{\text {tem }}=1.0 \\
& C_{\text {alt }}=1.0+0.001 \cdot a_{\mathrm{s}} \\
& \quad a_{\mathrm{s}}=160 \mathrm{~m} \mathrm{n} \cdot \mathrm{m} . \\
& C_{\text {alt }}=1.0+0.001 \cdot a_{\mathrm{s}}=1.0+0.001 \cdot 160=1.16 \\
& \mathrm{~V}_{\text {ref }}=C_{\text {dir }} \cdot C_{\text {tem }} \cdot C_{\text {alt }} \cdot v_{0}=1.0 \cdot 1.0 \cdot 1.16 \cdot 22.0=25.5 \mathrm{~m} / \mathrm{s} \\
& \mathrm{W}_{\text {ref }}^{\prime}=\frac{\rho_{\mathrm{zr}}}{2} \cdot \mathrm{v}_{\text {ref }}^{2}=\frac{1.25}{2} \cdot 25.5^{2}=406.4 \frac{\mathrm{kg} \cdot \mathrm{m}}{\mathrm{s}^{2}} \cdot \frac{1}{\mathrm{~m}^{2}}=0.406 \mathrm{kN} / \mathrm{m}^{2} \\
& \rho_{\mathrm{zr}}=1.25 \mathrm{~kg} / \mathrm{m}^{3}
\end{aligned}
$$

Djelovanje vjetra na visini $9 \mathrm{~m}$ iznad tla:

$$
\begin{gathered}
\mathrm{w}_{\text {ref }}=\mathrm{c}_{\mathrm{r}}(\mathrm{z}) \cdot \mathrm{c}_{\mathrm{t}}(\mathrm{z}) \cdot \mathrm{w}_{\text {ref }}^{\prime}=\left[\mathrm{k}_{\mathrm{r}} \cdot \ln \left(\mathrm{z} / \mathrm{z}_{0}\right)\right] \cdot 1.0 \cdot 0.406=[0.19 \cdot \ln (9.0 / 0.05)] \cdot 1.0 \cdot 0.406= \\
=0.987 \cdot 1.0 \cdot 0.406=0.400 \mathrm{kN} / \mathrm{m}^{2}
\end{gathered}
$$

Koeficijent sile: $c_{f}=1.00$

Dinamički koeficijent sile: $c_{d}=1.0$ (iz dijagrama) (slika 11).

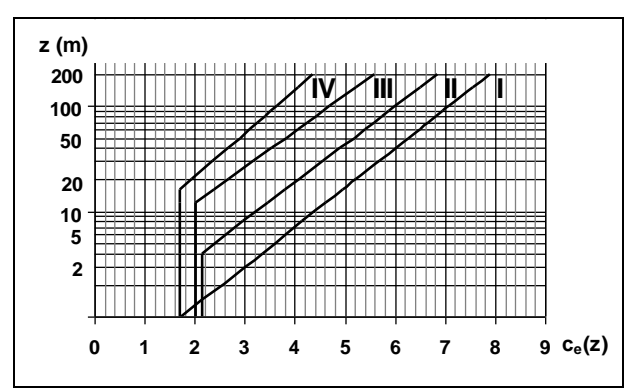

\section{Slika 11 - Dijagram za određivanje koeficijenta izloženosti vjetru u ovisnosti o visini iznad tla}

Koeficijent položaja $c_{e}(z)$ za kategoriju terena II i prosječnu visinu do $17 \mathrm{~m}$ iznad terena: $c_{e}(z)=3.6$ 
Rezultirajuće opterećenje vjetrom: $w=w_{\text {ref }} \cdot c_{e}(z) \cdot c_{d} \cdot c_{f}=0.40 \cdot 3.6 \cdot 1.0 \cdot 1.0=1.44 \mathrm{kN} / \mathrm{m}^{2}$

\section{$\underline{\text { Temperatura }}$}

Temperaturno djelovanje zbog razlika u temperaturi kod montaže čelične konstrukcije (otvoreni objekt) uzeto je u proračunu konstrukcije preko jednolike temperature $t_{s}=50^{\circ} \mathrm{C}$.

\section{$\underline{\text { Potres }}$}

Potresne sile proračunate su pojednostavljenim postupkom proračuna. Građevina je smještena u 8. potresnoj zoni prema važećoj seizmičkoj karti. Usvojeno projektno ubrzanje tla je $\alpha=0.2 \mathrm{~g}$.

Građevina je temeljena na glinovitom tlu visoke plastičnosti nepoznate dubine, što odgovara klasi tla C („Duboke naslage dobro do srednje zbijenog pijeska, šljunka ili gline, debljine od nekoliko desetina do više stotina metara"), prema parametrima danim u geotehničkom elaboratu. Pretpostavlja se srednja klasa ponašanja: DCM (medium ductility)

$$
\begin{aligned}
& \alpha=\frac{a_{g}}{g}=0.2 \\
& S=1.15 \\
& \beta_{0}=2.5 \\
& \eta=1.0 \\
& T_{B}=0.20 ; T_{C}=0.6 \quad ; \quad T_{D}=2.0
\end{aligned}
$$

Faktor značaja: $\gamma=1.20$ (zgrada povećane seizmičke otpornosti).

Faktor ponašanja q:

$$
\begin{aligned}
q= & q_{0} \cdot k_{d} \cdot k_{r} \cdot k_{w} \\
& q_{0} \text { - osnovna vrijednost faktora ponašanja; } q_{0}=5.0 \text { (okvirni sustav) } \\
& k_{d} \text { - faktor klase duktilnosti; uzima se srednja klasa duktilnosti }(M) ; k_{d}=0.75 \\
& k_{r} \text { - faktor pravilnosti konstrukcije; } k_{r}=1.0 \text { - pravilna konstrukcija } \\
& k_{w}-\text { faktor loma, } k_{w}=1.0 \text { - okvirni sustav } \\
q= & 5.0 \cdot 0.75 \cdot 1.0 \cdot 1.0=3.75
\end{aligned}
$$

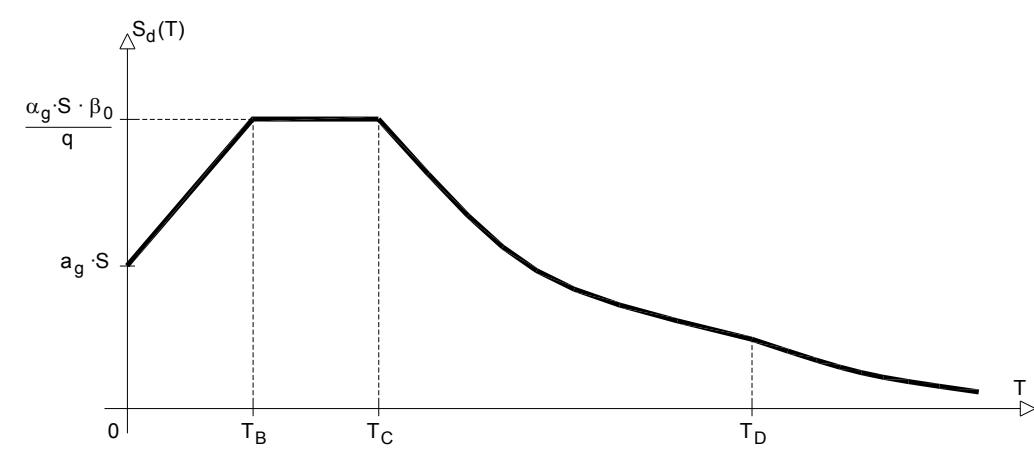

\section{Slika 12 - Proračunski spektar ubrzananja prema EC8}

Za seizmički koeficijent bira se maksimalna vrijednost: $T_{B}<T_{i}<T_{C}$ :

$$
S_{d}\left(T_{i}\right)=\alpha \cdot S \cdot \frac{\beta_{0}}{q}=0.2 \cdot 1.15 \cdot \frac{2.5}{3.75}=0.15
$$

Građevina potresne sile preuzima obodnim zidovima, stupovima i gredama, te jezgrama. 


\section{Puzanje betona}

Vrijednost koeficijenta puzanja $\varphi\left(t, t_{0}\right)$ prema Dodatku B HRN ENV 1992-1-1:

$$
\varphi\left(t, t_{0}\right)=\varphi_{0} \cdot \beta_{c}\left(t, t_{0}\right)
$$

$\varphi_{0}$ je osnovni koeficijent puzanja. Pretpostavlja se da će se konstrukcija značajnije opteretiti 28 dana nakon stvrdnjavanja betona.

$$
\begin{aligned}
& \mathrm{h}_{0}=723 \mathrm{~mm} \\
& \varphi_{0}=\varphi_{\mathrm{RH}} \cdot \beta\left(\mathrm{f}_{\mathrm{cm}}\right) \cdot \beta\left(\mathrm{t}_{0}\right) \\
& \text { pri čemu je: } \\
& \text { - } \varphi_{\mathrm{RH}} \text { - koeficijent koji uzima u obzir relativnu vlažnost } \\
& \text { - } \beta\left(\mathrm{f}_{\mathrm{cm}}\right) \text { - koeficijent koji uzima u obzir čvrstoću betona } \\
& \text { - } \beta\left(t_{0}\right) \text { - koeficijent koji uzima u obzir starost betona u trenutku nanošenja opterećenja } \\
& \varphi_{\mathrm{RH}}=1+\frac{1-\mathrm{RH} / 100}{0.1 \cdot \sqrt[3]{\mathrm{h}_{0}}}=1+\frac{1-80 / 100}{0.1 \cdot \sqrt[3]{723}}=1.223 \\
& \beta\left(\mathrm{f}_{\mathrm{cm}}\right)=\frac{16.8}{\sqrt{\mathrm{f}_{\mathrm{cm}}}}=\frac{16.8}{\sqrt{30}}=3.067 \\
& \beta\left(\mathrm{t}_{0}\right)=\frac{1}{\left(0.1+\mathrm{t}_{0}^{0.20}\right)}=\frac{1}{\left(0.1+28^{0.20}\right)}=0.488 \\
& \varphi_{0}=1.223 \cdot 3.067 \cdot 0.488=1.830
\end{aligned}
$$

\section{Numerički model konstrukcije}

Za potrebe proračuna izrađeni su štapno-pločasti modeli. Modeli su proračunati programskim paketom "Aspalathos" programom za analizu linijskih i pločastih sustava. Posebno su napravljeni modeli za svaku dilataciju, jer su one i fizički odvojene, osim na nivou temeljne ploče (slika 13). Na temeljnoj ploči je adekvatno podešenim rubnim uvjetima simuliran kontinuitet.

Model je opterećen stalnim opterećenjem (vlastita težina konstrukcije i nekonstrukcijskih elemenata) te korisnim opterećenjem, pri čemu su sva opterećenja zadana kao raspodijeljena opterećenja po pločama. Korisno opterećenje je uvećano za 20\% (npr. u Supermarketu na: $12.0 \mathrm{kN} / \mathrm{m}^{2}$ ) da bi se izbjeglo postavljanje pokretnog opterećenja u najnepovoljnije položaje.

Rezultati numeričkog proračuna su prikazani za pojedinačne slučajeve opterećenja, kao i za računsko (granično, ultimativno) opterećenje. Uobičajena kombinacija opterećenja se dobiva kao kombinacija stalnog i pokretnog opterećenja te opterećenja snijega i vjetra, prema izrazu:

$$
e=1.35 g+1.5(q+s+w)
$$

Izvanredna kombinacija opterećenja se dobiva kao kombinacija stalnog i pokretnog opterećenja te potresa, prema izrazu:

$$
e=1.0 g+1.0 \psi_{02} q+1.0 \Delta
$$



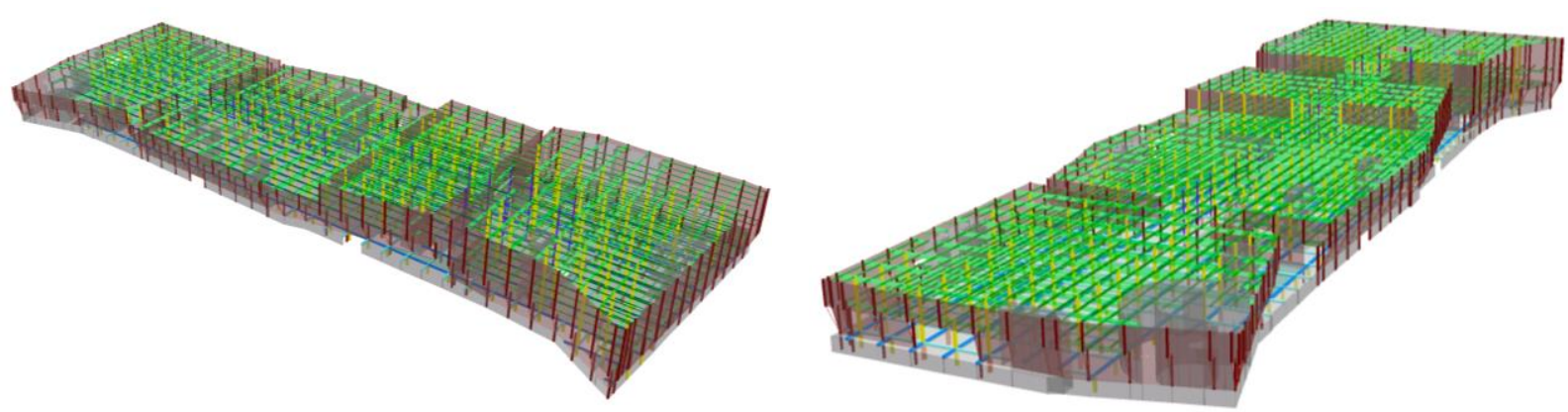

Slika 13 - Neki prikazi renderiranog numeričkog modela građevine

\section{Proračun konstrukcije na vertikalna opterećenja}

\subsection{Temeljna ploča}

Temeljna ploča je modelirana kao ploča na elastičnoj podlozi, u okviru globalnih modela dilatacija. Momenti u temeljnoj ploči dobiveni su kroz numerički model s koeficijentom reakcije podloge $K=2100,0 \mathrm{kN} / \mathrm{m}^{3}$. Na slici 14 je prikazan jedan dio temeljne ploče s relevantnim rezultatima.
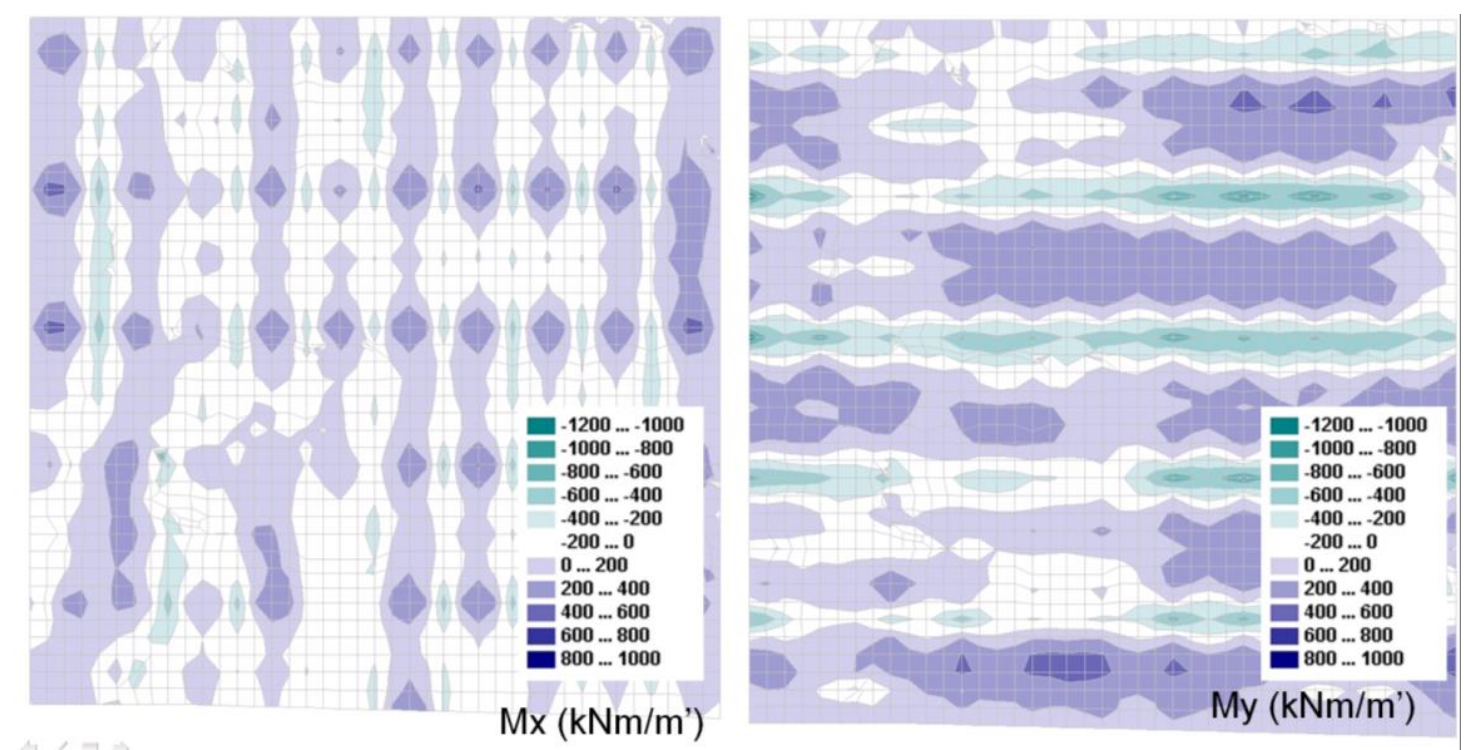

\section{Slika 14 - Prikaz momenata u temeljnoj ploči}

Potrebna armatura i način postavljanja prikazan je na slici 15. 

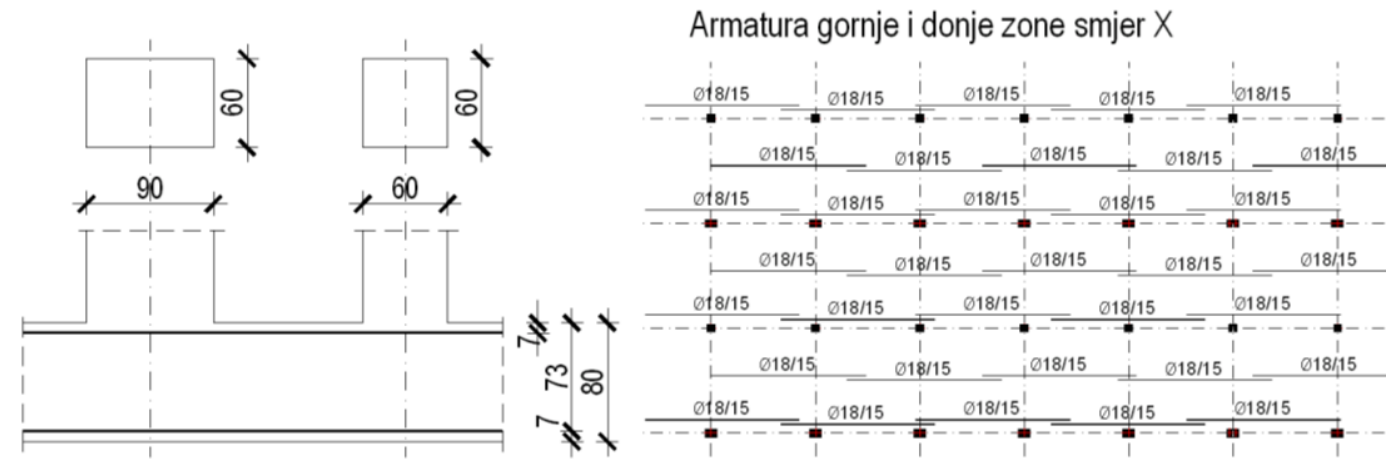

Armatura donje zone smjer $Y$

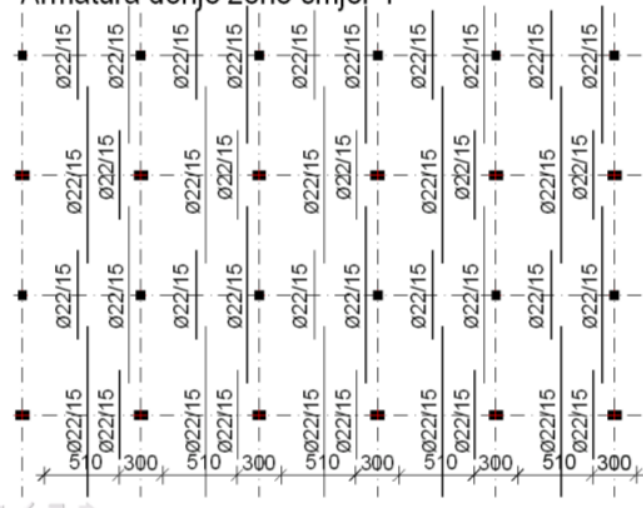

Armatura gornje zone smjer $Y$

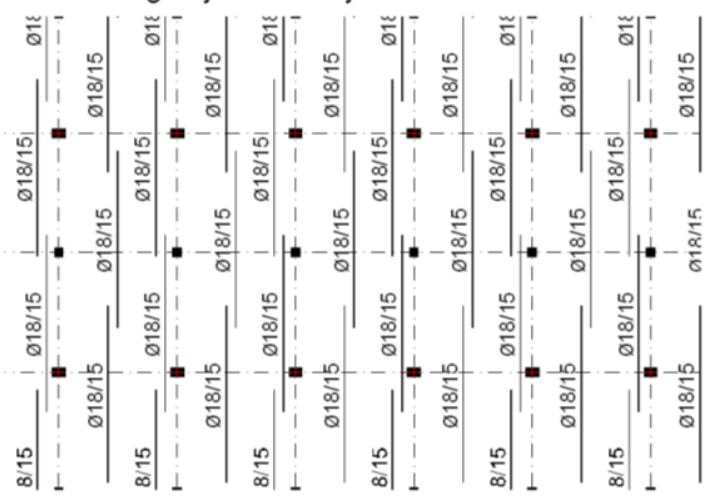

\section{Slika 11 - Skica armature ploča}

Iz modela su također očitane maksimalne uzdužne sile u stupovima pri dnu stupa u garaži. Za sve stupove kontroliran je proboj stupa kroz ploču. Kontrola proboja izvršena je za kombinaciju opterećenja:

$$
e=1.35 g+0.71 .35 q
$$

Armatura protiv proboja izvedena je pomoću „jahača“ (armatura za pridržanje armature u gornjoj zoni) (slika 16):

\begin{tabular}{|c|c|c|c|c|c|c|c|c|c|c|}
\hline \multirow{2}{*}{\multicolumn{2}{|c|}{ Stup }} & \multirow{3}{*}{$\begin{array}{l}\text { Dimenzije } \\
(\mathrm{cm}) \\
60 \times 60\end{array}$} & \multirow{3}{*}{$\frac{b}{1.1}$} & \multirow{2}{*}{$\begin{array}{c}\text { Opseg } \\
u_{\mathrm{cr}}(\mathrm{cm})\end{array}$} & \multirow{2}{*}{$\begin{array}{c}\text { Sila } \\
\mathrm{N}_{\mathrm{sd}}[\mathrm{kN}]\end{array}$} & \multirow{2}{*}{$\begin{array}{l}\text { Težina pl. } \\
\mathrm{N}_{\mathrm{sd}}[\mathrm{kN}]\end{array}$} & \multirow{2}{*}{$\begin{array}{l}\text { Sila prob. } \\
v_{\mathrm{sd}}[\mathrm{kN} / \mathrm{cm}]\end{array}$} & \multirow{2}{*}{$\begin{array}{c}\text { Arm atura } \\
A_{s}\left[\mathrm{~cm}^{2}\right]\end{array}$} & \multicolumn{2}{|c|}{ Odabrana Armatura } \\
\hline & & & & & & & & & Šipaka & Povr. $\left[\mathrm{cm}^{2}\right]$ \\
\hline $\mathrm{y} 13$ & $\times 01$ & & & 928.0 & 2930.8 & 325.0 & 3.09 & & & \\
\hline $\mathrm{y} 12$ & $\times 01$ & $60 \times 60$ & 1.1 & 928.0 & 1973.9 & 650.0 & 1.57 & & & \\
\hline$y 11$ & $x 01$ & $60 \times 90$ & 1.1 & 988.0 & 3931.1 & 650.0 & 3.65 & & & \\
\hline$y 10$ & $x 01$ & $60 \times 60$ & 1.1 & 928.0 & 2521.5 & 650.0 & 2.22 & & & \\
\hline y09 & $\times 01$ & $60 \times 90$ & 1.1 & 988.0 & 3343.3 & 650.0 & 3.00 & & & \\
\hline y06 & $x 01$ & $60 \times 60$ & 1.1 & 928.0 & $\begin{aligned} 518.2 \\
\end{aligned}$ & 650.0 & -0.16 & & & \\
\hline$y 13$ & $\times 02$ & $60 \times 60$ & 1.1 & 928.0 & 4704.0 & 650.0 & 4.81 & 31.26 & $8 \varnothing 18$ & 40.72 \\
\hline$y 12$ & $\times 02$ & $60 \times 60$ & 1.1 & 928.0 & 2094.5 & 1300.0 & 0.94 & & & \\
\hline $\mathrm{y} 11$ & $x 02$ & $60 \times 90$ & 1.1 & 988.0 & \begin{tabular}{l|l}
5802.7 \\
\end{tabular} & 1300.0 & 5.01 & 39.96 & $8 \varnothing 18$ & 40.72 \\
\hline$y 10$ & $\times 02$ & $60 \times 60$ & 1.1 & 928.0 & 3490.4 & 1300.0 & 2.60 & & & \\
\hline y09 & $\times 02$ & $60 \times 90$ & 1.1 & 988.0 & 5583.9 & 1300.0 & 4.77 & 32.13 & $8 \varnothing 18$ & 40.72 \\
\hline$y 08$ & $x 02$ & $60 \times 60$ & 1.1 & 928.0 & 2104.3 & 1300.0 & 0.95 & & & \\
\hline y07 & $\times 02$ & $60 \times 90$ & 1.1 & 988.0 & 5498.2 & 1300.0 & 4.67 & 29.06 & $8 \varnothing 18$ & 40.72 \\
\hline y06 & $x 02$ & $60 \times 200$ & 1.1 & 1208.0 & $\begin{array}{l}921.4 \\
\end{array}$ & 650.0 & 0.25 & & & \\
\hline $\mathrm{y} 12$ & $\times 03$ & $60 \times 60$ & 1.1 & 928.0 & 2018.3 & 650.0 & 1.62 & & & \\
\hline$y 11$ & $x 03$ & $60 \times 90$ & 1.1 & 988.0 & 5971.8 & 1300.0 & 5.20 & 46.01 & $8 \varnothing 18$ & 40.72 \\
\hline$y 10$ & $\times 03$ & $60 \times 60$ & 1.1 & 928.0 & 1979.8 & 1300.0 & 0.81 & & & \\
\hline y09 & $\times 03$ & $60 \times 90$ & 1.1 & 988.0 & 6072.2 & 1300.0 & 5.31 & 49.60 & $8 \varnothing 18$ & 40.72 \\
\hline y08 & $x 03$ & $60 \times 60$ & 1.1 & 928.0 & 2062.6 & 1300.0 & 0.90 & & & \\
\hline y07 & $\times 03$ & $60 \times 90$ & 1.1 & $\begin{array}{l}988.0 \\
\end{array}$ & 5771.9 & 1300.0 & 4.98 & 38.86 & $8 \varnothing 18$ & 40.72 \\
\hline y06 & $\times 03$ & $60 \times 200$ & 1.1 & 1208.0 & 964.0 & 650.0 & 0.29 & & & \\
\hline$y 12$ & $x 04$ & $60 \times 60$ & 1.1 & 928.0 & $\begin{array}{l}1871.7 \\
\end{array}$ & 650.0 & 1.45 & & & \\
\hline$y 11$ & $\times 04$ & $60 \times 90$ & 1.1 & 988.0 & $\begin{array}{l}6078.4 \\
\end{array}$ & 1300.0 & 5.32 & 49.82 & $8 \varnothing 18$ & 40.72 \\
\hline$y 10$ & $\times 04$ & $60 \times 60$ & 1.1 & 928.0 & $\begin{array}{l}1974.9 \\
\end{array}$ & 1300.0 & 0.80 & & & \\
\hline y09 & $x 04$ & $60 \times 90$ & 1.1 & 988.0 & $\begin{array}{l}6177.6 \\
\end{array}$ & 1300.0 & 5.43 & 53.37 & $8 Ø 18$ & 40.72 \\
\hline y08 & $\times 04$ & $60 \times 60$ & 1.1 & 928.0 & 2021.2 & 1300.0 & 0.85 & & & \\
\hline y07 & $\times 04$ & $60 \times 90$ & 1.1 & 988.0 & 6186.4 & 1300.0 & 5.44 & 53.69 & $8 \varnothing 18$ & 40.72 \\
\hline y06 & $\times 04$ & $60 \times 60$ & 1.1 & 928.0 & 1670.9 & 650.0 & 1.21 & & & \\
\hline y05 & $\times 04$ & $60 \times 90$ & 1.1 & 988.0 & 4123.2 & 1300.0 & 3.14 & & & \\
\hline y04 & $\times 04$ & $60 \times 60$ & 1.1 & 928.0 & $\begin{array}{l}1571.3 \\
\end{array}$ & $\begin{array}{l}650.0 \\
\end{array}$ & 1.09 & & & \\
\hline $\mathrm{y} 12$ & $\times 05$ & $60 \times 60$ & 1.1 & 928.0 & $\begin{array}{l}1744.9 \\
\end{array}$ & 650.0 & 1.30 & & & \\
\hline$y 11$ & $\times 05$ & $60 \times 90$ & 1.1 & 988.0 & 6138.2 & 1300.0 & 5.39 & 51.96 & $8 \varnothing 18$ & 40.72 \\
\hline y10 & $\times 05$ & $60 \times 60$ & 1.1 & 928.0 & 1971.0 & 1300.0 & 0.80 & & & \\
\hline$y 09$ & $\times 05$ & $60 \times 90$ & 1.1 & 988.0 & $\begin{array}{ll}6157.3 \\
\end{array}$ & 1300.0 & 5.41 & 52.64 & $8 \varnothing 18$ & 40.72 \\
\hline
\end{tabular}




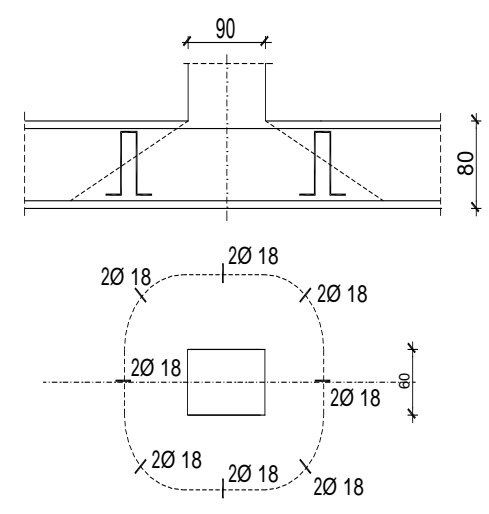

Slika 16 - Primjer proračuna na proboj i skica armature protiv proboja

\subsection{Ploča nad garažom}

Ploča nad garažom modelirana je, skupa s pripadnim gredama, numeričkim programom. Primjer izlaznih rezultata za ploču prikazani su na slici 17.

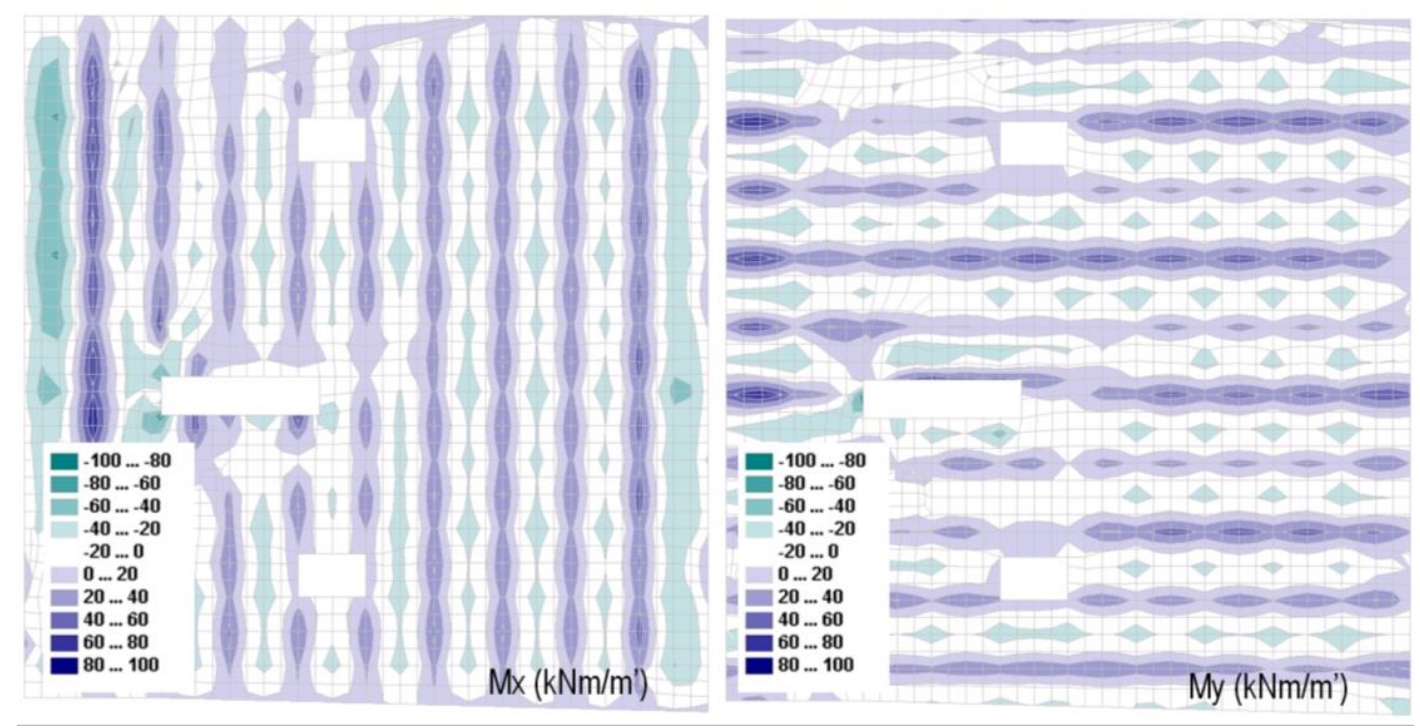

Slika 17 - Prikaz momenata u ploči nad garažom

Ploča je dimenzionirana za momente savijanja, standardnim postupkom prema EC-2.

$$
\begin{aligned}
& \text { C 30/37 } \quad \mathrm{f}_{\mathrm{cd}}=\frac{\mathrm{f}_{\mathrm{ck}}}{\gamma_{\mathrm{c}}}=\frac{30}{1.5}=20.0 \mathrm{MPa} ; \quad \mathrm{f}_{\mathrm{cd}}=2.0 \mathrm{kN} / \mathrm{cm}^{2} \\
& \text { B } 500 \quad f_{y d}=\frac{f_{y k}}{\gamma_{s}}=\frac{500}{1.15}=435 \mathrm{MPa} ; \quad f_{y d}=43.5 \mathrm{kN} / \mathrm{cm}^{2} \\
& b=100 \mathrm{~cm} \quad h=22 \mathrm{~cm} ; \quad d=19 \mathrm{~cm} \\
& \begin{array}{l}
\mu_{s d s}^{*}=0.235 ; \quad \zeta \approx 0.850 \quad \varepsilon_{c} / \varepsilon_{s}=3.5 / 5.0 \\
M_{R d, c, l i m}=\mu_{s d s}^{*} b d^{2} f_{c d}=0.159 \cdot b d^{2} f_{c d} \\
M_{R d, s, \text { lims }}=A_{s} \zeta d f_{y d}
\end{array}
\end{aligned}
$$




$$
\begin{aligned}
& A_{s 1, \text { min }}=0.1 \% b h=0.001 \cdot 100 \cdot 22=2.2 \mathrm{~cm}^{2} \\
& A_{s 1, \text { max }}=2.0 \% b h=0.020 \cdot 100 \cdot 22=44.0 \mathrm{~cm}^{2}
\end{aligned}
$$

U tablici 3 prikazani su ultimativni momenti nosivosti za odabranu mrežastu armaturu.

Tablica 3 - Ultimativni momenti nosivosti za odabranu mrežastu armaturu

\begin{tabular}{|c|c|c|c|c|}
\hline \multirow{2}{*}{ Šipke } & Površina $A_{s 1}$ & $\begin{array}{c}\text { Moment nosivosti betona } \\
M_{\text {Rd,c,lim }}\end{array}$ & $\begin{array}{c}\text { Moment nosivosti armature } \\
M_{\text {Rd,s,lim }}\end{array}$ & $\begin{array}{c}\text { Postotak } \\
\text { armature }\end{array}$ \\
\cline { 2 - 5 } & {$\left[\mathrm{cm}^{2} / \mathrm{m}^{\prime}\right]$} & {$[\mathrm{kNm}]$} & {$[\mathrm{kNm}]$} & $\%$ \\
\hline \hline $\mathrm{R} / \mathrm{Q}-503$ & 5.03 & 169.67 & 37.42 & 0.26 \\
\hline $\mathrm{R} / \mathrm{Q}-626$ & 6.26 & 169.67 & 46.57 & 0.33 \\
\hline $\mathrm{R} / \mathrm{Q}-785$ & 7.85 & 169.67 & 58.39 & 0.41 \\
\hline
\end{tabular}

Zbog preraspodjele kod dugotrajnih efekata, sva armatura u polju je birana nešto veća od izračunate, a armatura na ležajevima u skladu s izračunatom. Skica armature prikazana je na slikama 18 i 19.

Slika 18 - Armaturni plan ploče nad garažom - donja zona - detalj 


\section{Slika 19 - Armaturni plan ploče nad garažom - gornja zona - detalj}

\subsection{Grede nad garažom}

Kako je već naglašeno, konstrukcija ploče garaže je armiranobetonska monolitna konstrukcija koja se sastoji od armiranobetonskih ploča $(\mathrm{d}=22 \mathrm{~cm}$ ) koje su povezane gredama $65 \times 60 \mathrm{~cm}$ (smjer sjever-jug) i $60 \times 60 \mathrm{~cm}$ (smjer istokzapad) (slika 20). Garaža je djelomično ukopana i ukrućena obodnim zidovima za horizontalna opterećenja.
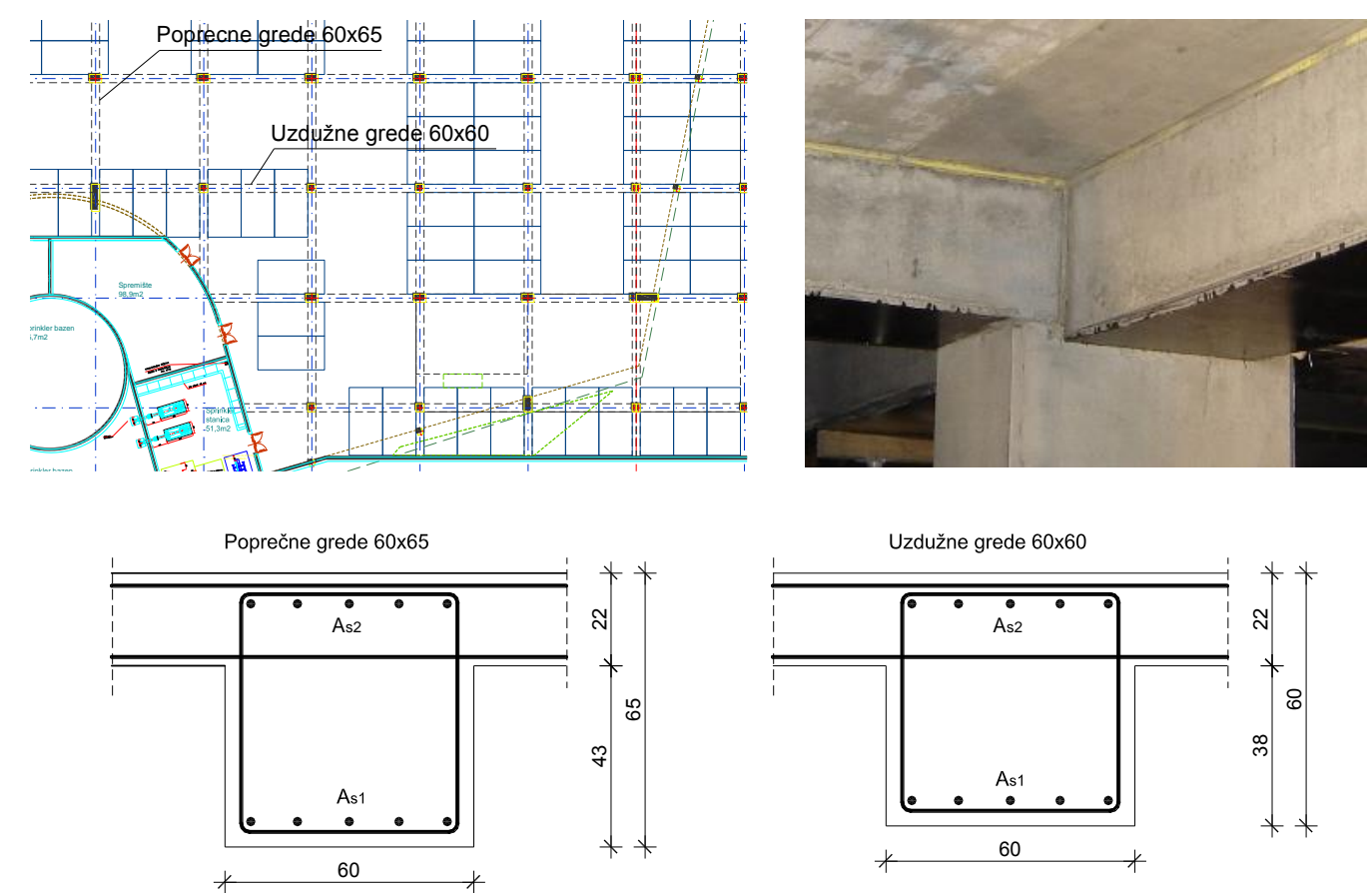

Slika 20 - Prikaz greda nad garažom - detalj 
Pri modeliranju ploča nad garažom modelirana je, skupa s pripadnim gredama. Primjer izlaznih rezultata za neke grede prikazani su na slici 21.

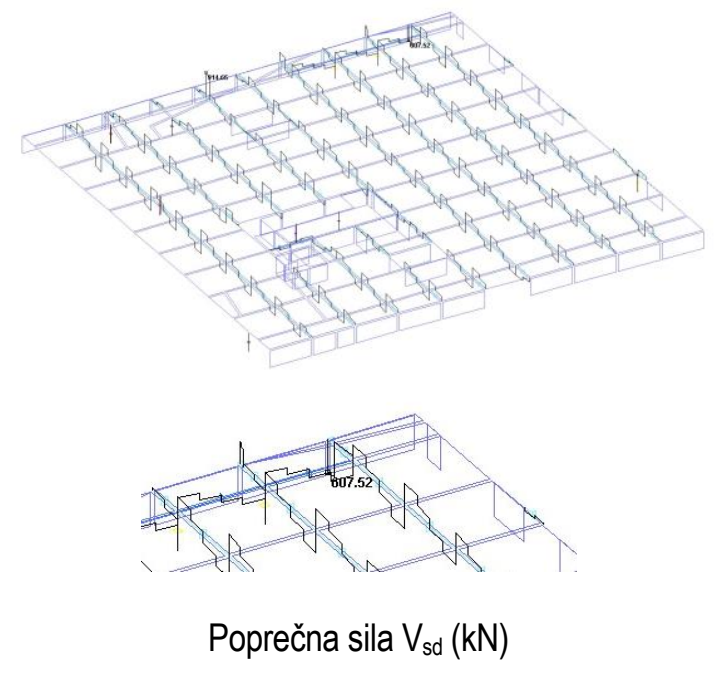

Slika 21 - Prikaz unutarnjih sila u gredama nad garažom

Grede su dimenzionirane na momente savijanja i poprečnu silu, standardnim postupkom prema EC-2 (slika 22).

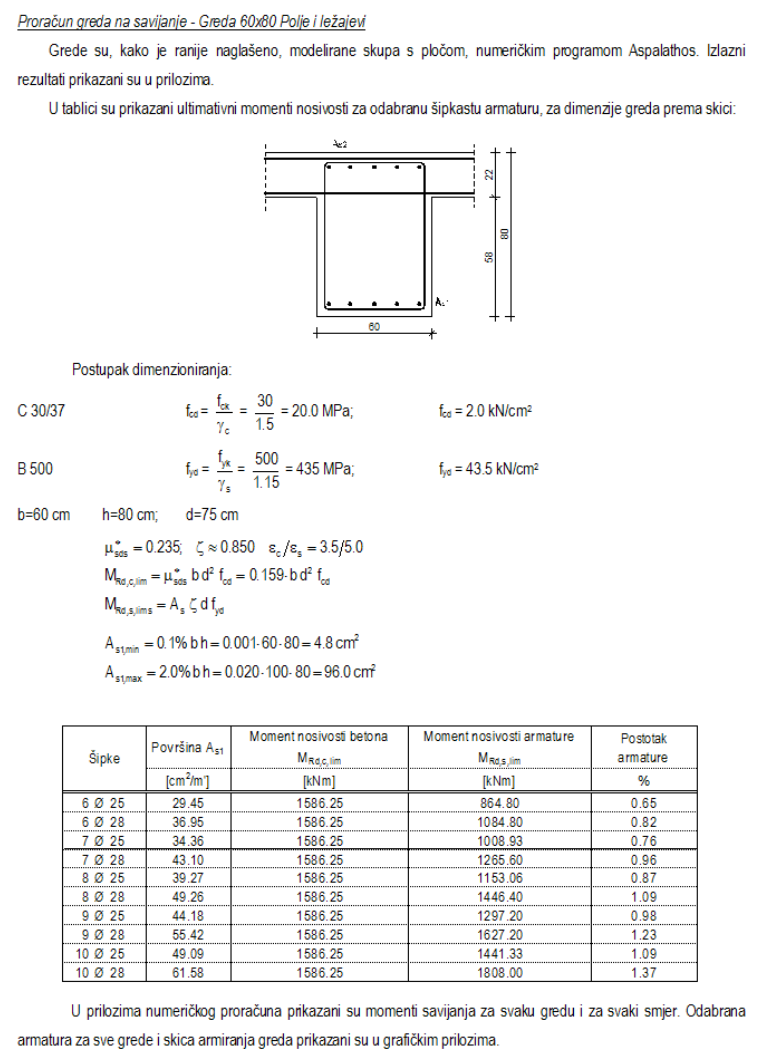

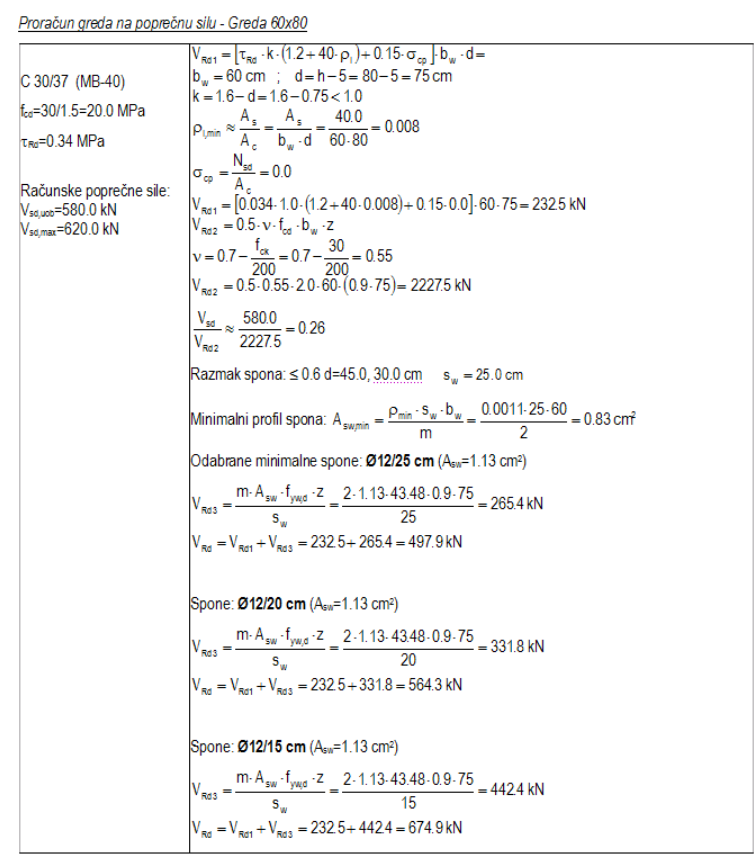

Odabrane spone u polju: Ø12/20 cm $\left(\mathrm{A}_{\mathrm{su}}=1.13 \mathrm{~cm} \mathrm{~cm}^{2}\right), \mathrm{m}=2$. Vidljivo je da u vecíni slučajeva ove spone mogu u potpunosti preuzeti računsku poprečnu silu. U ostalim slučajevima spone se progušcavaju na $15 \mathrm{tj}$. na $10 \mathrm{~cm}$. Skica armiranja greda prikazana je u grafíckim prilozima.

\section{Slika 22 - Izvadak iz rada - prikaz proračuna greda nad garažom}


Prijedlog armiranja greda dan je na slikama 23 i 24.

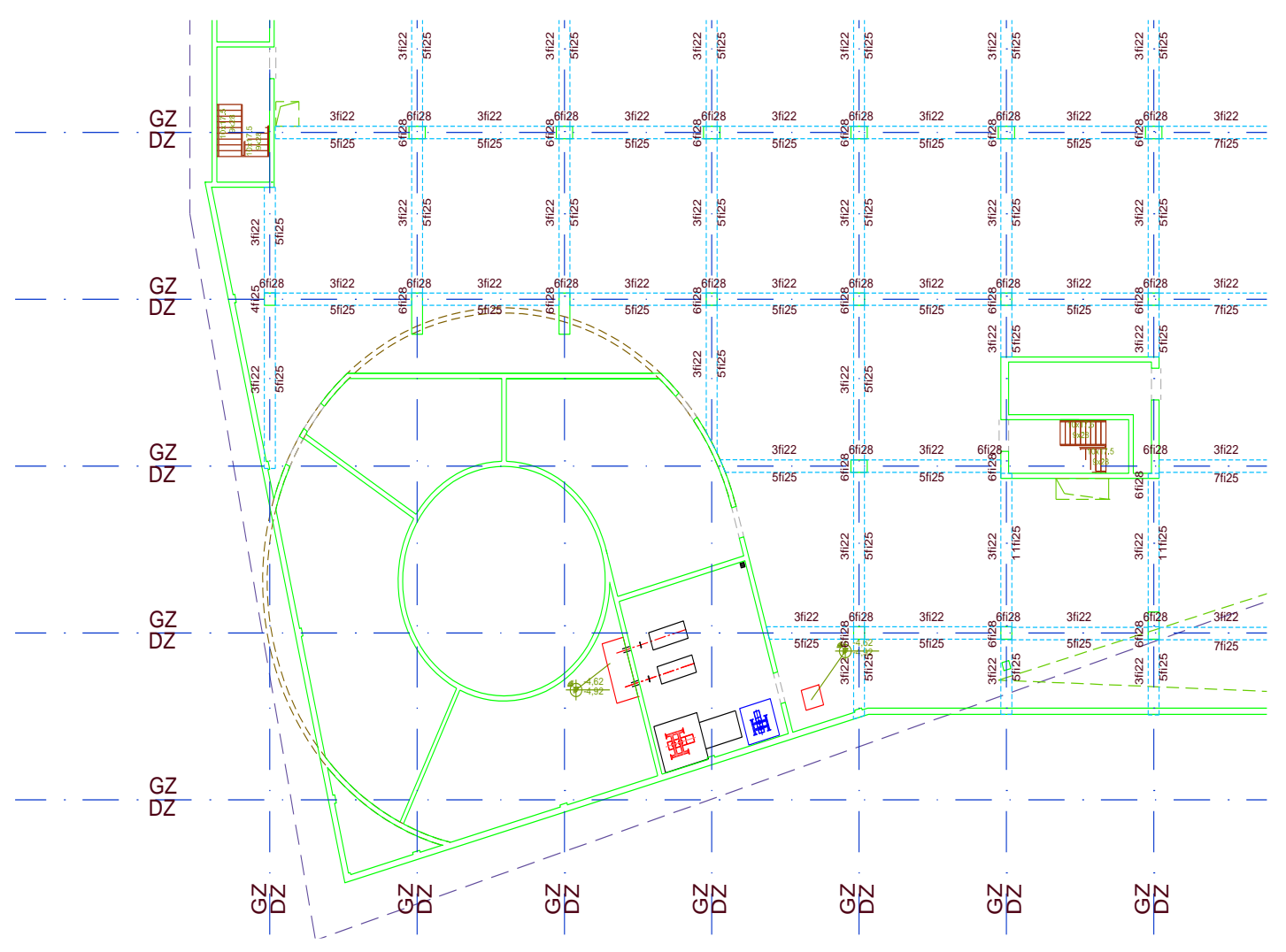

Slika 23 - Skica armature u gredama
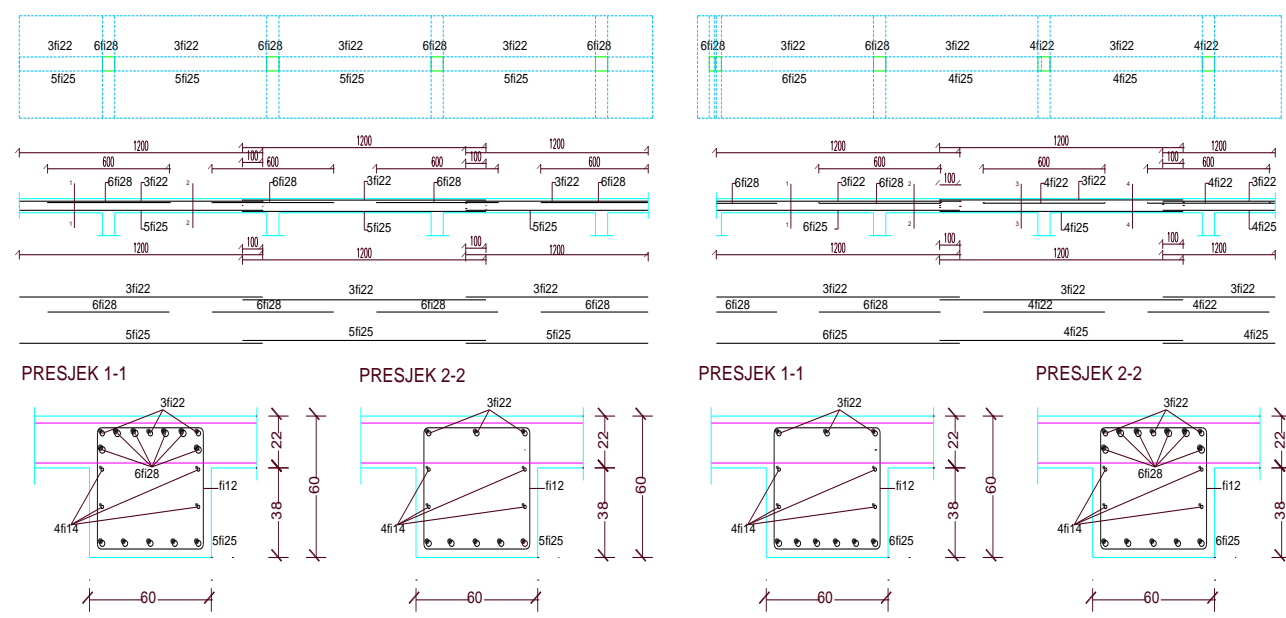

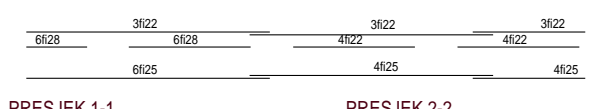

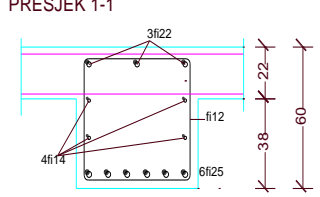

$\uparrow 60-1$

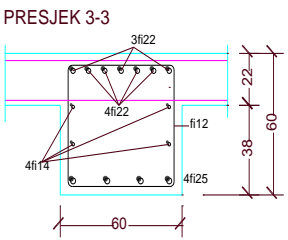

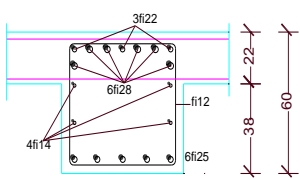

$160-1$

PRESJEK 4-4

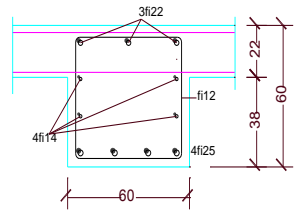

Slika 24 - Armaturni plan nekih greda nad garažom 
Za izabrane (najopterećenije) grede također su kontrolirane širine pukotina postupkom propisanim prema EC-2 (slika 25), te progibi približnim postupkom (slika 26).

Dilatacije 2, 3i 4 - Kontrola pukotina, ploća $d=22 \mathrm{~cm}$

Mjerodavni momenti u ploă su dobiveni kroz numerički model. Koriste se rezultati od kratkotrajnog djelovanja i radne kombinacije opterećenja $(e=1.0 \cdot g+1.0 \cdot q)$.

Granična vrijednost širine pukotine: $W_{g}=0.3 \mathrm{~mm}(E C-2-$ uobičajena sredina $)$

Proračunska vrijednost širine pukotine: $(E C-2)$ :

$$
w_{\mathrm{k}}=\beta \cdot s_{\mathrm{m}} \cdot \varepsilon_{\mathrm{sm}} \leq w_{g}
$$

Maksimalni eksploatacijski (radni) moment u polju: $\mathrm{M}_{\mathrm{so}}=25.0 \mathrm{kNm}$

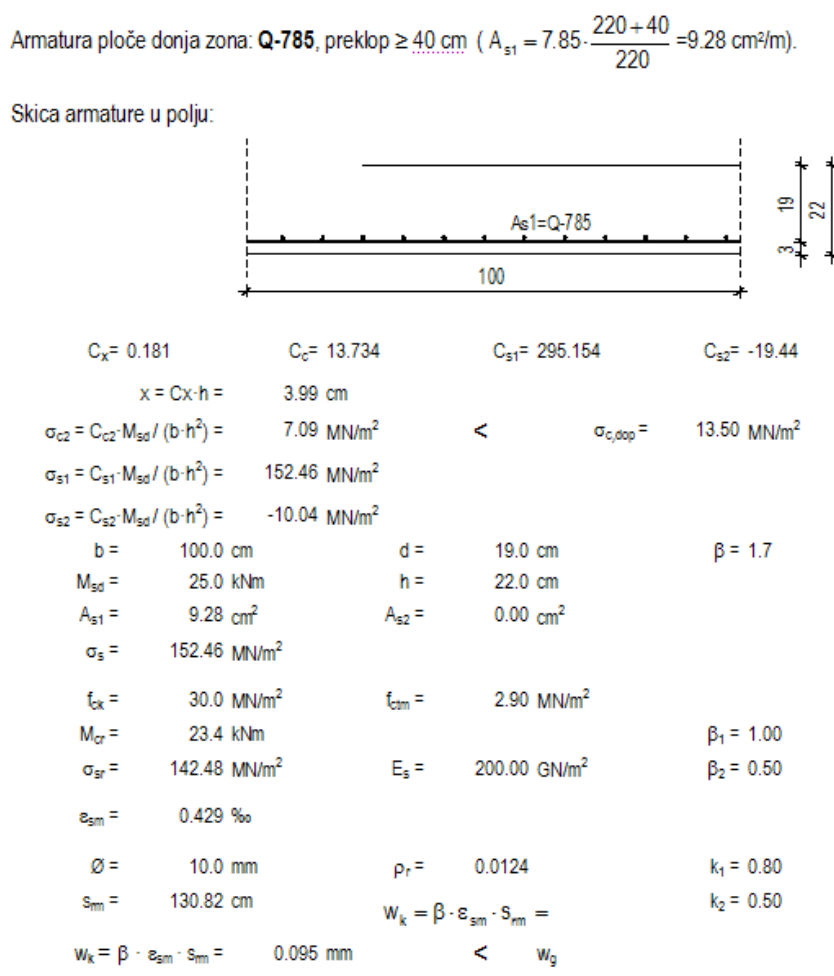

Pukotine zadovoljavaju!

Slika 25 - Izvadak iz rada - prikaz proračuna pukotina na gredama 


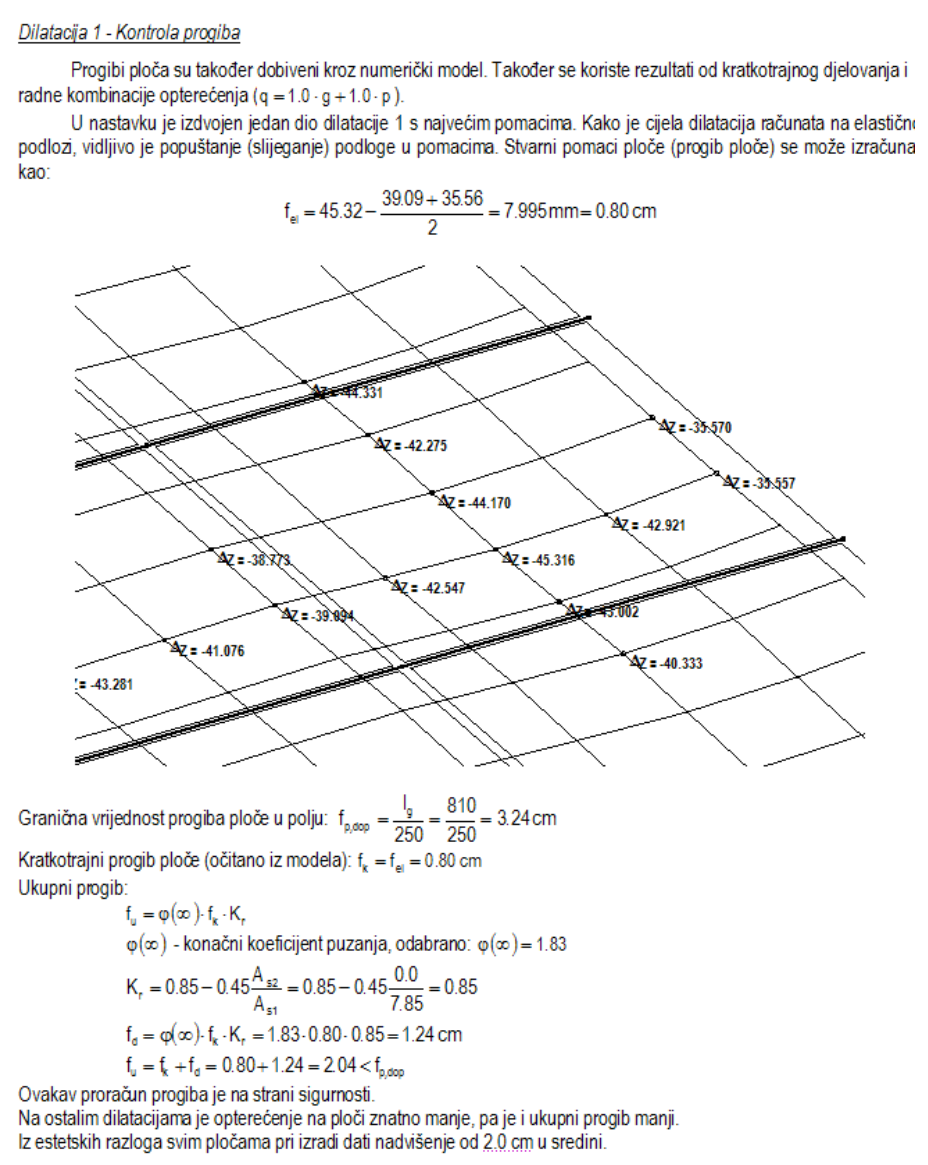

Slika 26 - Izvadak iz rada - prikaz proračuna progiba na gredama

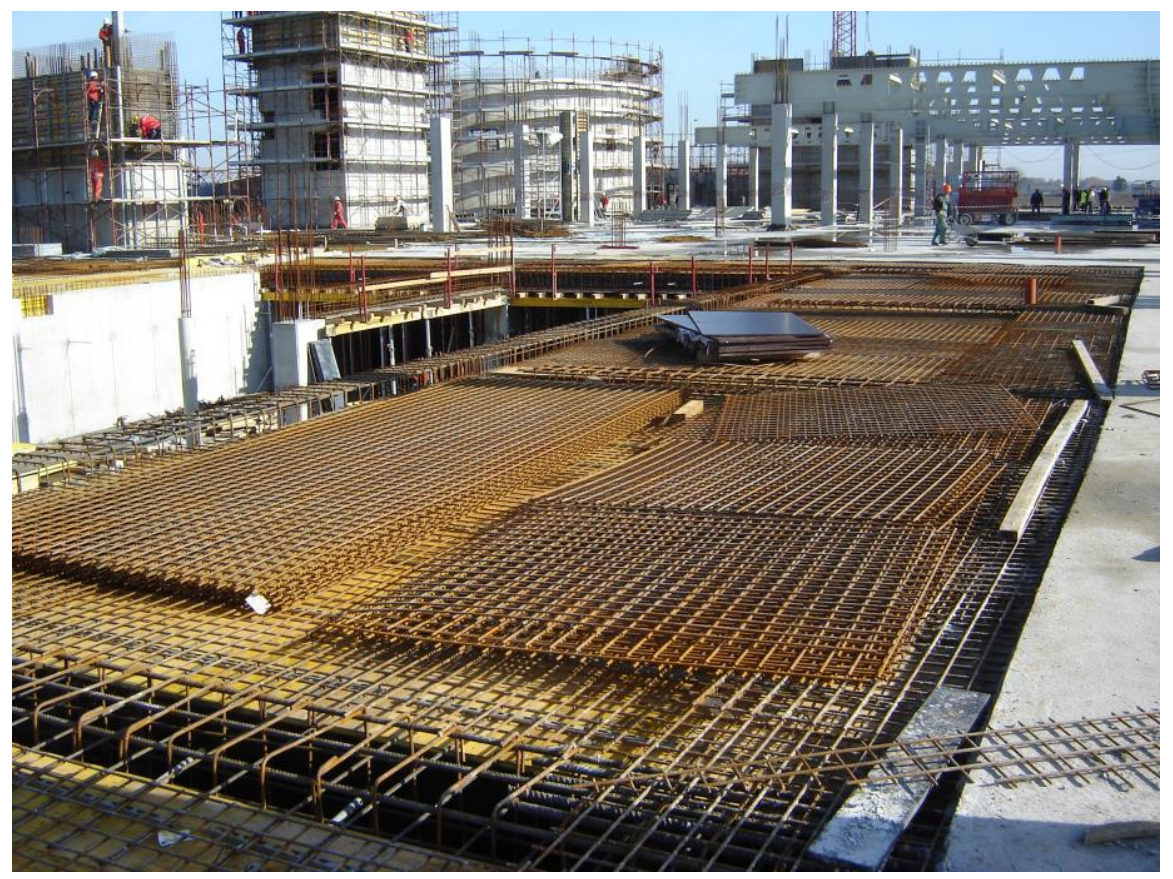

Slika 27 - Detalji izvođenja greda i ploča nad garažom 


\section{$9 \quad$ Proračun konstrukcije na horizontalna opterećenja}

\subsection{Numerički model}

Svi elementi konstrukcije kontrolirani su i za horizontalna opterećenja. Kao mjerodavno horizontalno opterećenje pokazao se potres. Konstrukcija je na potres analizirana metodom spektralnog (višemodalnog) odgovora. Potresne sile proračunate su postupkom prema prednormi EC-8. Ukupne sile proračunate su CQC metodom. U nastavku su prikazani neki rezultati za odabranu dilatacijsku cjelinu (2. dilatacija).

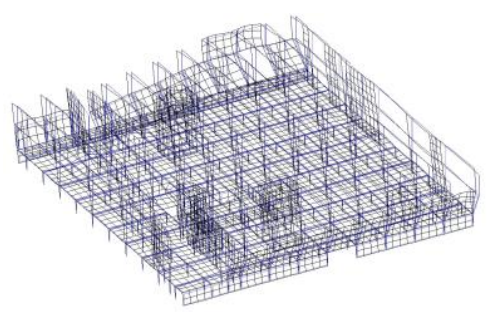

1. ton, $\mathrm{T}=0.34 \mathrm{~s}$

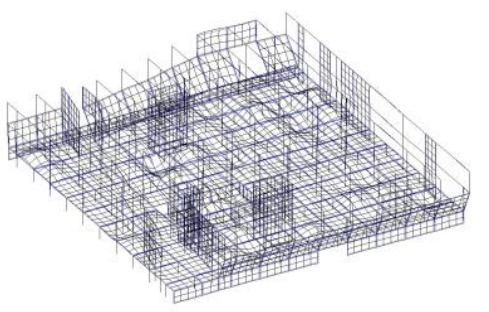

2. ton, $\mathrm{T}=0.32 \mathrm{~s}$

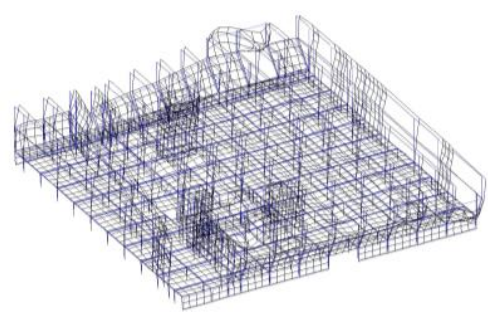

3. ton, $\mathrm{T}=0.31 \mathrm{~s}$

\section{Slika 28 - Prikaz tonova osciliranja konstrukcije}

Detaljni rezultati modalnog proračuna sortirani su u tablici 4.

Tablica 4 - Prikaz perioda, frekvencija i aktivirane mase za prvih 20 tonova osciliranja

\begin{tabular}{|c||c||r|r|r|r|}
\hline \multirow{2}{*}{ Mod } & \multirow{2}{*}{$\begin{array}{c}\text { Period } \\
(\mathrm{s})\end{array}$} & Frekvencija & \multicolumn{3}{|c|}{ Aktivirana masa } \\
\cline { 3 - 6 } & \multicolumn{1}{|c||}{$(1 / \mathrm{s})$} & $\mathrm{x}(\%)$ & $\mathrm{y}(\%)$ & $\mathrm{z}(\%)$ \\
\hline \hline 1 & 0.3444 & 2.9033 & 1.12 & 63.03 & 0.00 \\
\hline 2 & 0.3185 & 3.1397 & 0.00 & 0.35 & 0.00 \\
\hline 3 & 0.3122 & 3.2034 & 0.00 & 0.09 & 0.00 \\
\hline 4 & 0.3069 & 3.2587 & 0.54 & 6.34 & 0.13 \\
\hline 5 & 0.3065 & 3.2631 & 0.02 & 1.55 & 0.01 \\
\hline 6 & 0.3043 & 3.2866 & 0.00 & 0.11 & 0.04 \\
\hline 7 & 0.3003 & 3.3303 & 0.03 & 0.00 & 0.13 \\
\hline 8 & 0.2966 & 3.3717 & 0.00 & 0.35 & 0.02 \\
\hline 9 & 0.2922 & 3.4220 & 0.01 & 0.19 & 0.25 \\
\hline 10 & 0.2907 & 3.4397 & 0.00 & 0.11 & 0.04 \\
\hline 11 & 0.2829 & 3.5350 & 0.01 & 0.02 & 0.20 \\
\hline 12 & 0.2778 & 3.6000 & 0.00 & 0.21 & 0.39 \\
\hline 13 & 0.2739 & 3.6508 & 0.12 & 0.02 & 0.96 \\
\hline 14 & 0.2658 & 3.7620 & 2.67 & 16.42 & 0.14 \\
\hline 15 & 0.2601 & 3.8445 & 0.18 & 0.13 & 0.03 \\
\hline 16 & 0.2535 & 3.9449 & 1.59 & 0.62 & 0.11 \\
\hline 17 & 0.2449 & 4.0840 & 19.61 & 0.04 & 0.01 \\
\hline 18 & 0.2370 & 4.2188 & 41.39 & 2.53 & 0.00 \\
\hline 19 & 0.2319 & 4.3126 & 9.09 & 0.27 & 0.45 \\
\hline 20 & 0.2243 & 4.4579 & 8.26 & 0.01 & 3.02 \\
\hline & & 84.64 & 92.39 & 5.93 \\
\hline
\end{tabular}




\subsection{Dimenzioniranje stupova}

Stupovi su predviđeni kao klasično armirani betonski elementi. Poprečni presjek glavnih stupova je $60 \times 60 \mathrm{~cm}$ na svim nadzemnim etažama i $60 \times 60$ i $60 \times 90 \mathrm{~cm}$ u garaži. Osim ovih stupova, prisutni su i stupovi $40 \times 40 \mathrm{~cm}$ koji su uglavnom betonski, a na pojedinim mjestima su čelični, ispunjeni betonom. Također su korišteni i okrugli stupovi $\varnothing 300 \mathrm{~mm}$ (čelična cijev ispunjena betonom) koji na pojedinim mjestima podupiru fasadu ili konstrukcijske elemente na višim etažama. Također, na mjestima gdje su dva stupa vrlo bliska (orijentacijski, gdje im je svijetli razmak $\leq 50 \mathrm{~cm}$ ), oba stupa su povezana u jedan jedinstveni stup koji tada ima geometriju zahtijevanu geometrijom same konstrukcije.

Stupovi se izvode kao monolitni elementi lijevani u četverostranoj oplati na licu mjesta. Za sve stupove predviđen je beton C 30/37, Øagr $\leq 32 \mathrm{~mm}$, te armatura B 500 . Zaštitni slojevi betona do armature iznose min. $3.5 \mathrm{~cm}$ (slika 32).
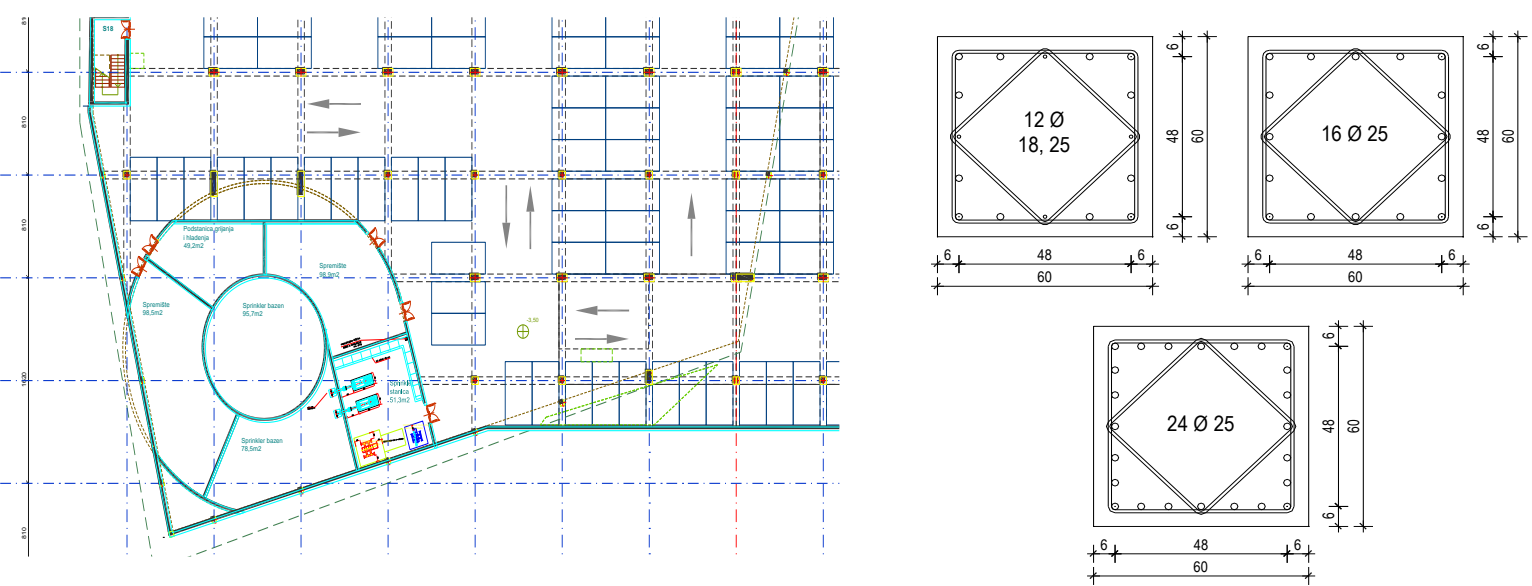

Slika 29 - Prikaz položaja stupova i poprečni presjek karakterističnog stupa $60 \times 60 \mathrm{~cm}$

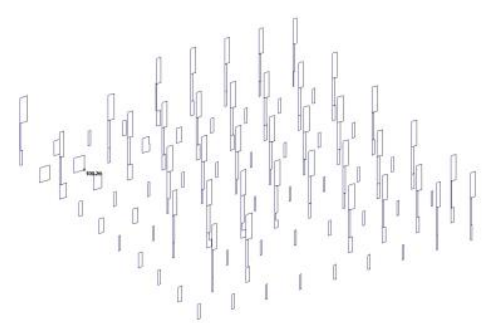

(a) Uzdužna sila $\mathrm{N}_{s d}(\mathrm{kN})$

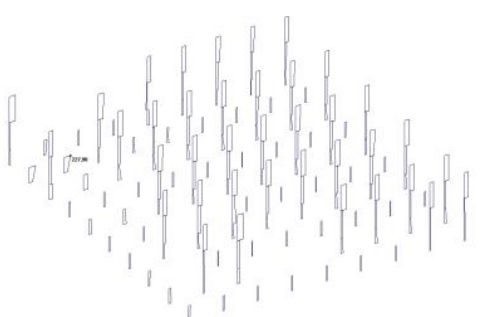

(b) Poprečna sila $V_{s d}(k N)$

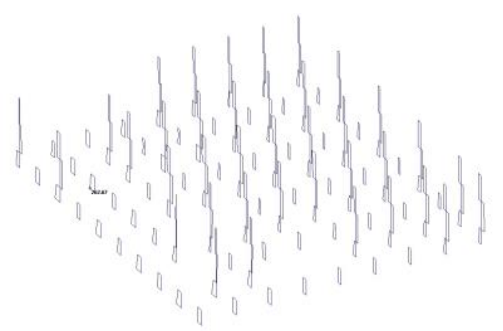

(c) Moment savijanja $\mathrm{M}_{\mathrm{sd}}(\mathrm{kNm})$

Slika 30 - Prikaz reznih sila za stupove garaže (potresna - CQC kombinacija opterećenja) 


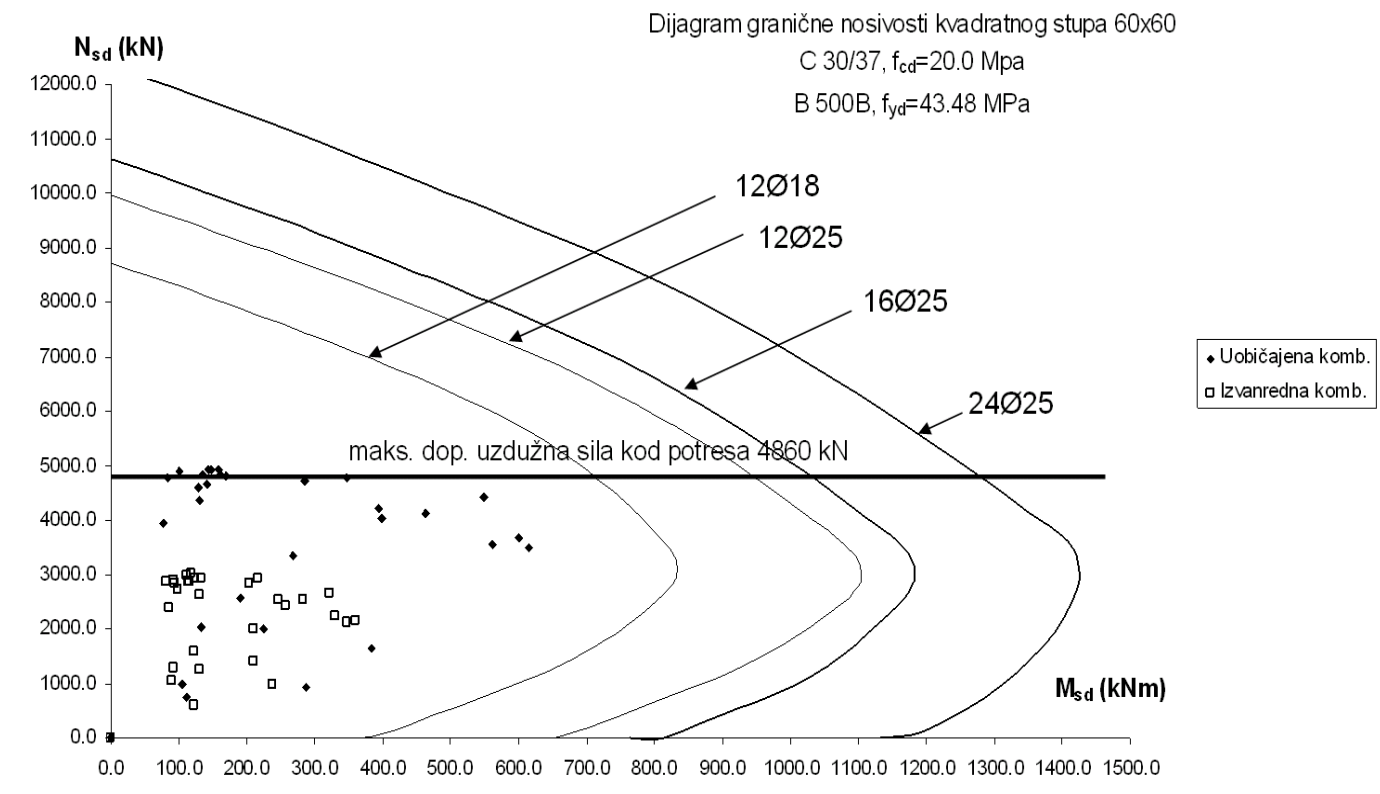

\section{Slika 31 - Dijagram nosivosti pravokutnog stupa $60 \times 60 \mathrm{~cm}$ sa zadanom armaturom}
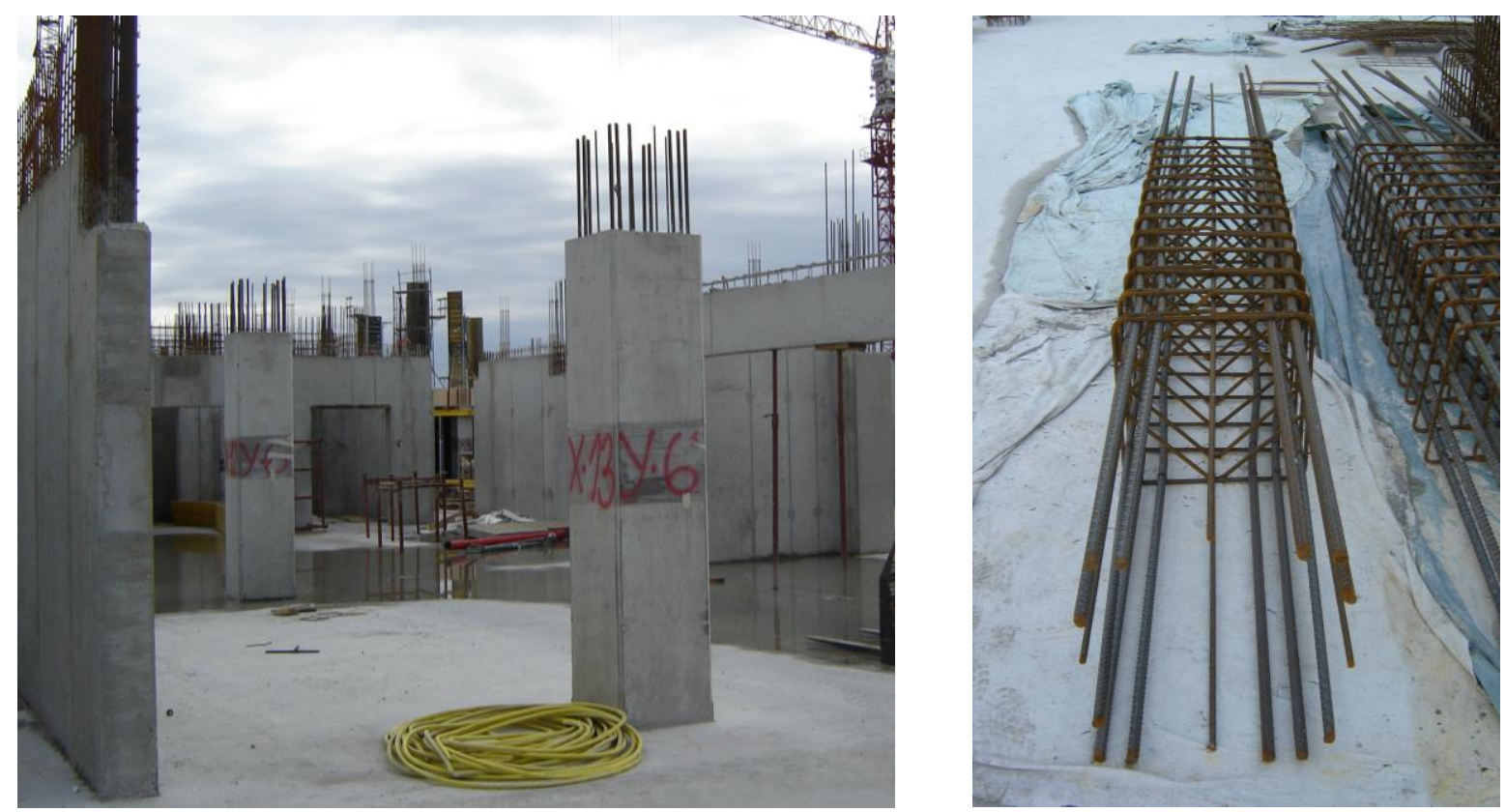

\section{Slika 32 - Izvedba stupova}

\subsection{Dimenzioniranje zidova}

Dominantni konstrukcijski sustav za prijam horizontalnih sila je okvirni sustav (sustav stupova i greda) koji je ukrućen jezgrama. U model su uključeni svi zidovi koji se kontinuirano protežu od prizemlja do vrha građevine, tj. oni koji su prikladno upeti u temeljnu ploču.

Ostali zidovi su "omekšani u modelu“ i ne služe prijenosu horizontalnih (potresnih) sila. Mjerodavno opterećenje je potresno opterećenje, tj. izvanredna kombinacija opterećenja. Zidovi su predviđeni kao klasično armirani betonski elementi. Debljina zidova je 42.5 i $25 \mathrm{~cm}$. Izvode se kao monolitni elementi lijevani u dvostranoj oplati na licu mjesta. Za sve zidove predviđen je beton C 30/37, $\varnothing_{\text {agr }} \leq 32 \mathrm{~mm}$, te armatura B 500B. Zaštitni slojevi betona do armature iznose min. $2.5 \mathrm{~cm}$. 


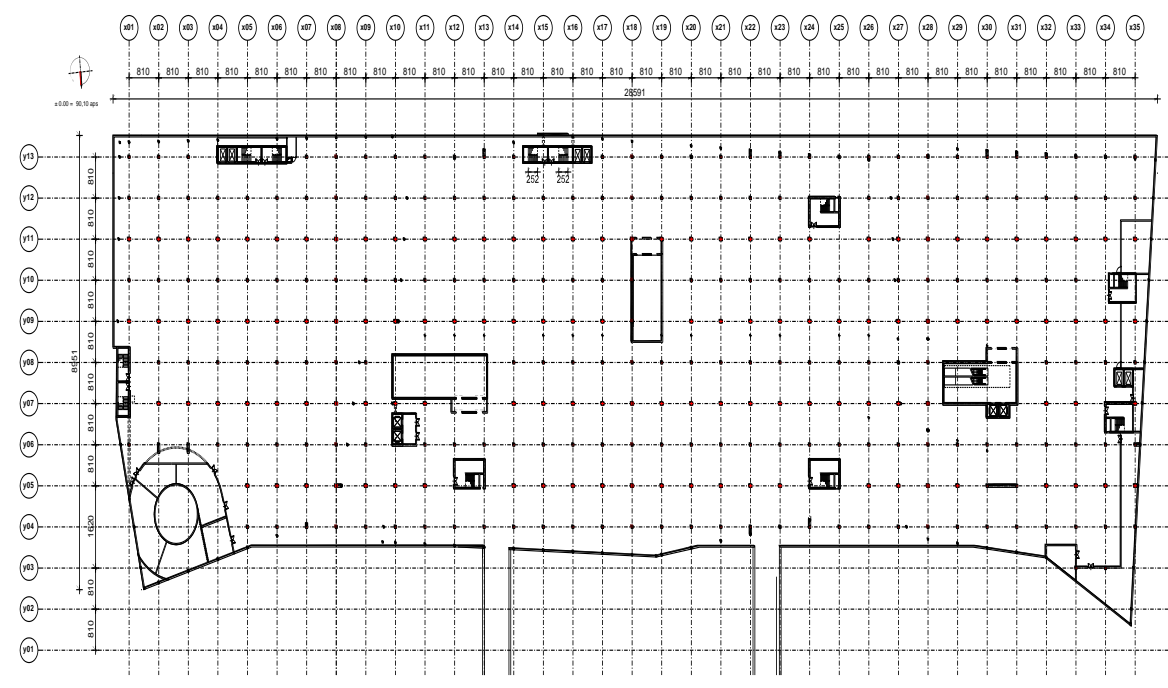

\section{Slika 34 - Prikaz položaja zidova}

Iz globalnog (prostornog) modela dobivena su mjerodavna naprezanja u zidovima. Sumiranjem ovih naprezanja dobivaju se mjerodavne sile za svaki zid (slika 34).

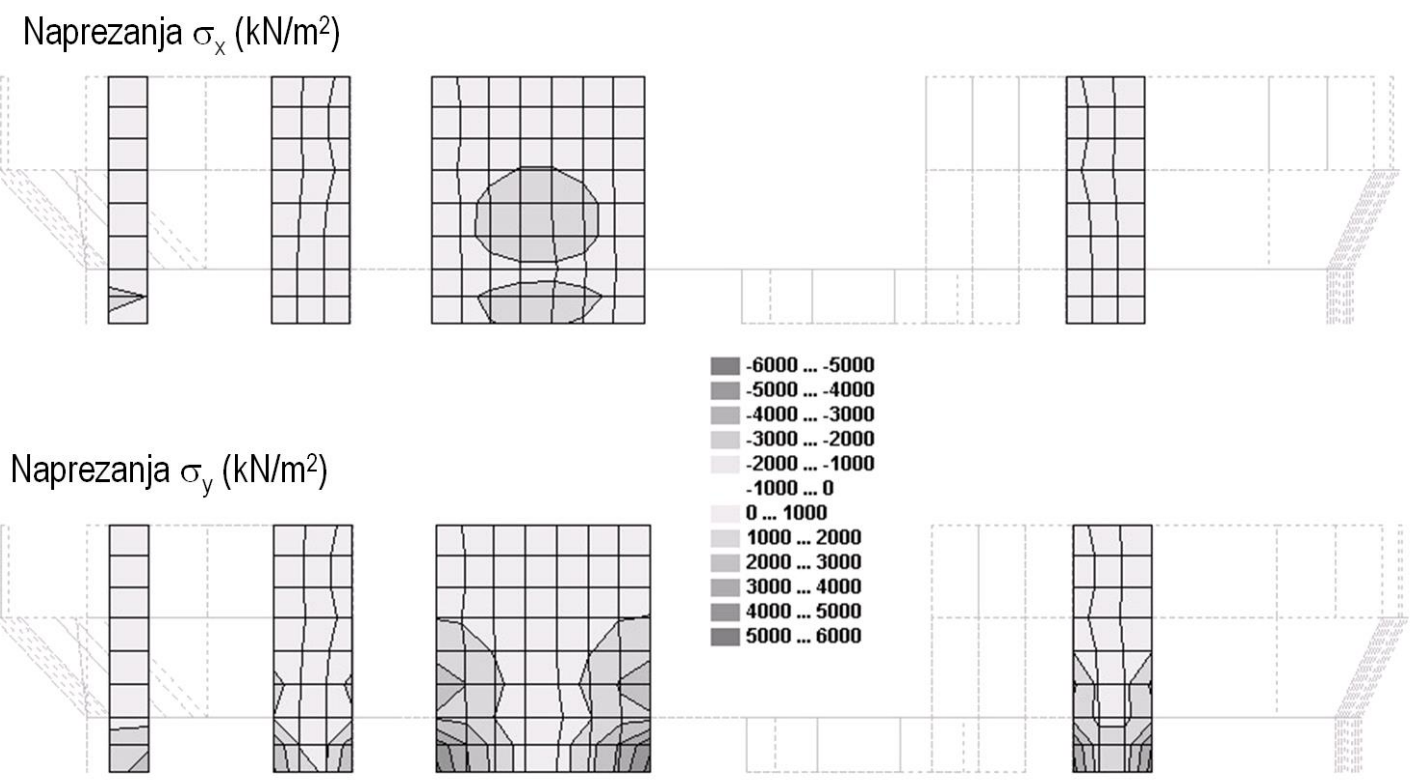

Slika 34 - Prikaz rezultata u nekom zidu 


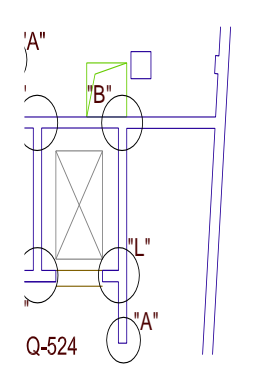

"L"

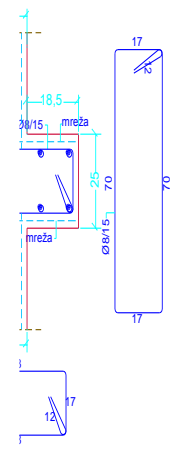
DETALJ "G"

\section{DETALJ "A"}
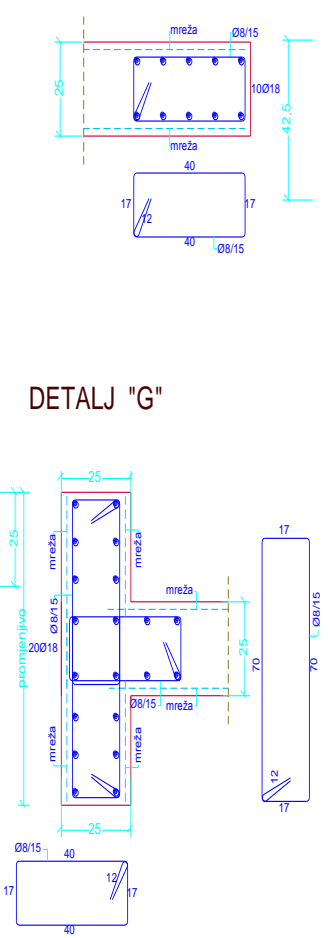

DETALJ "B"

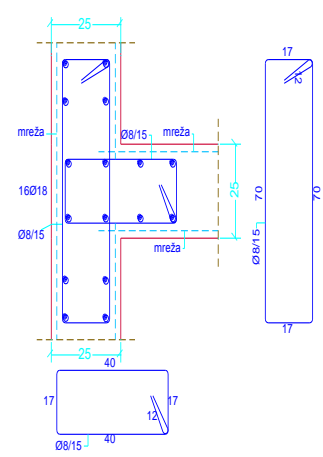

DETALJ "E"

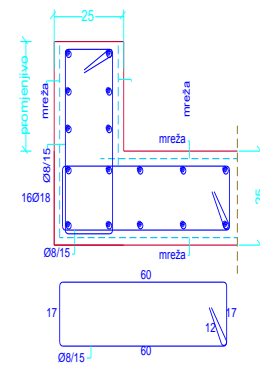

Slika 36 - Skica armature zidova
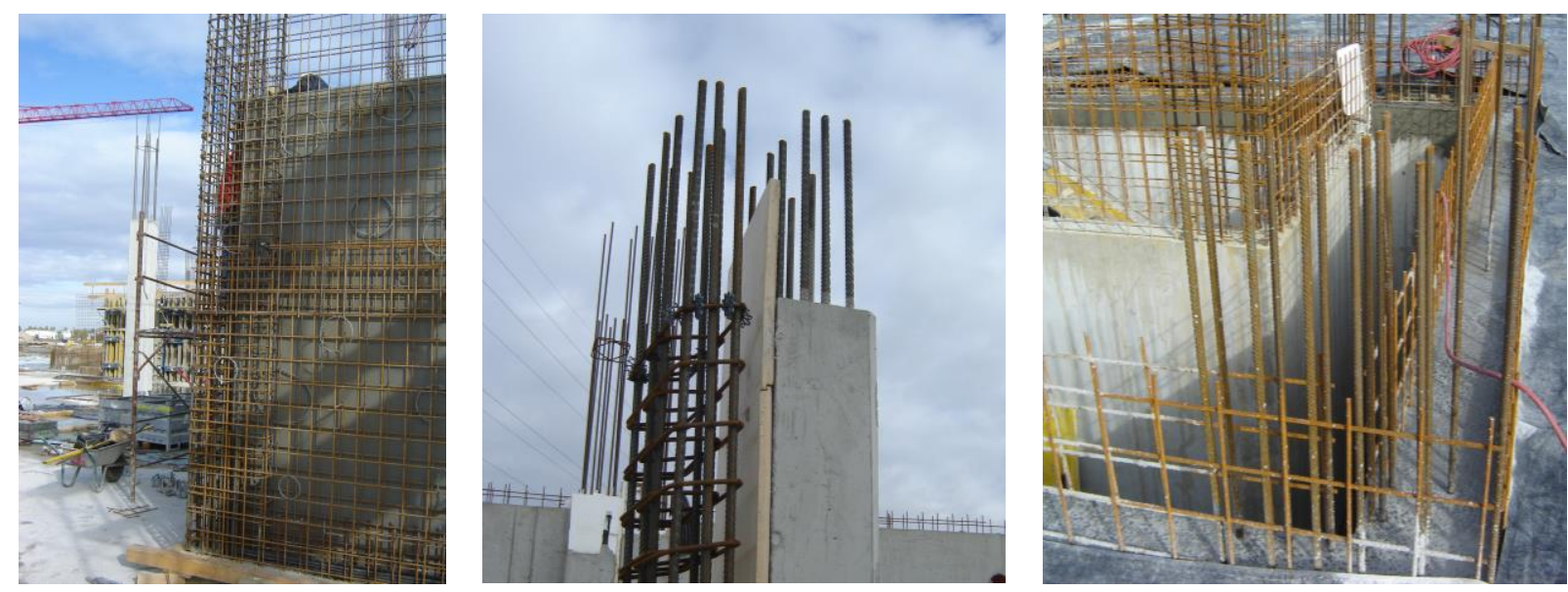

Slika 37 - Izvedba zidova

\subsection{Dimenzioniranje trapeznih i fasadnih zidova}

Zbog razvedenosti fasada i širenja građevine na prvom i drugom katu, u prizemlju su izvedeni tzv. trapezni zidovi koji imaju višestruku funkciju: oslonac za stupove na višim etažama, pridržanje kosih fasadnih zidova i oslonac čeličnog nosača nad prizemljem (slika 38). I ovi zidovi su obrađeni kroz numerički model te je izvršeno njihovo dimenzioniranje (određivanje potrebne površine armature) i kontrola pomaka i širine pukotina. Skica armature zidova dana je na slici 39, a neki detalji izvedbe na slikama 40 i 41. 


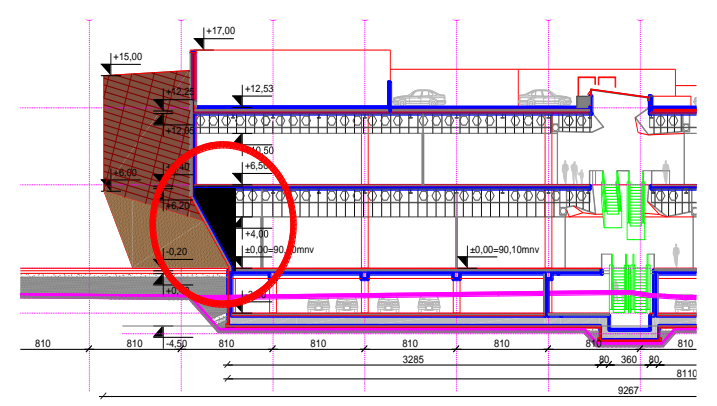

Slika 38 - Trapezni zidovi

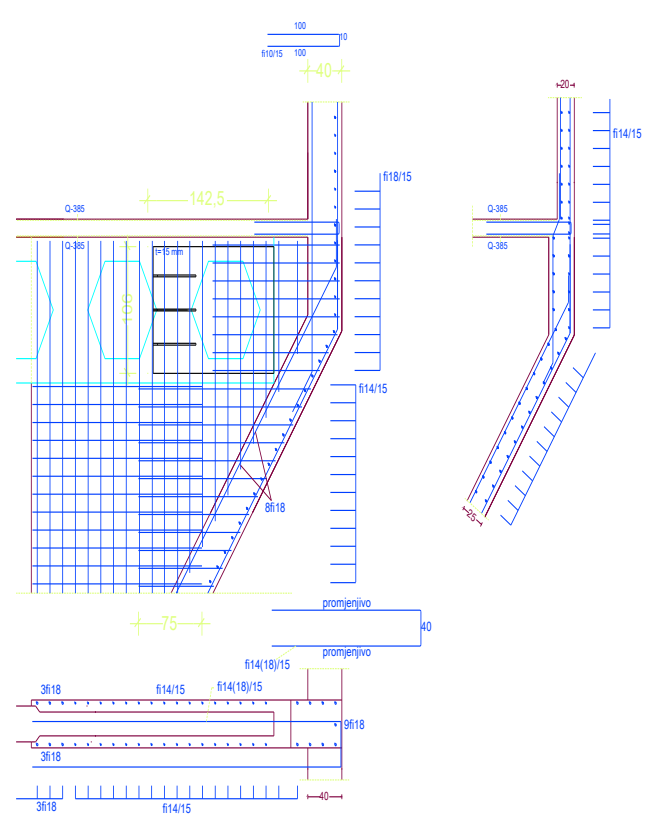

Slika 39 - Skica armature trapeznih i fasadnih zidova
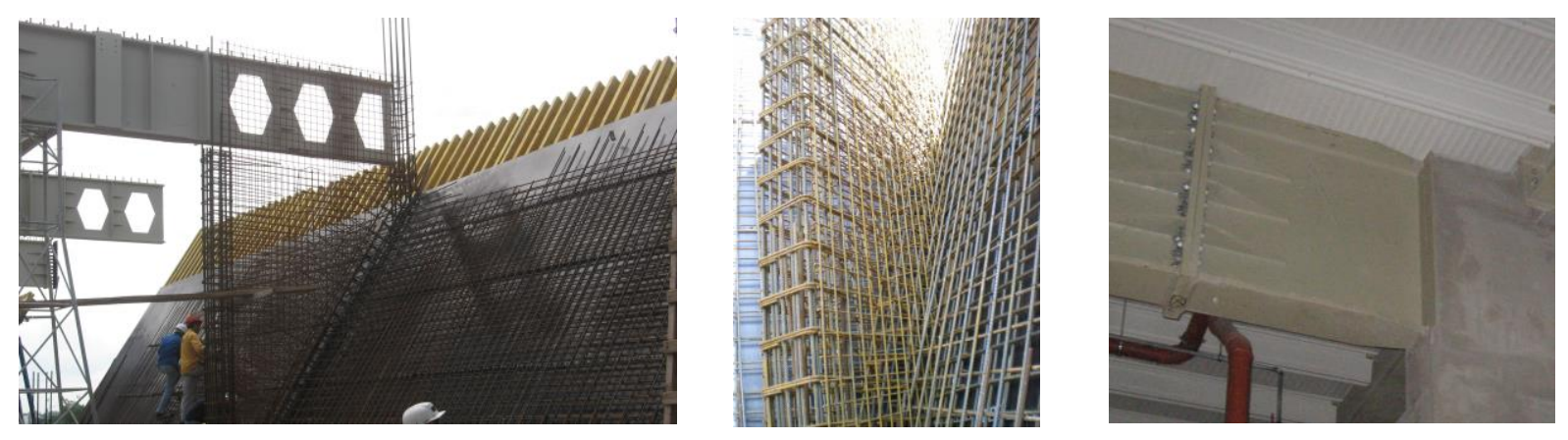

Slika 40 - Izvedba zidova 


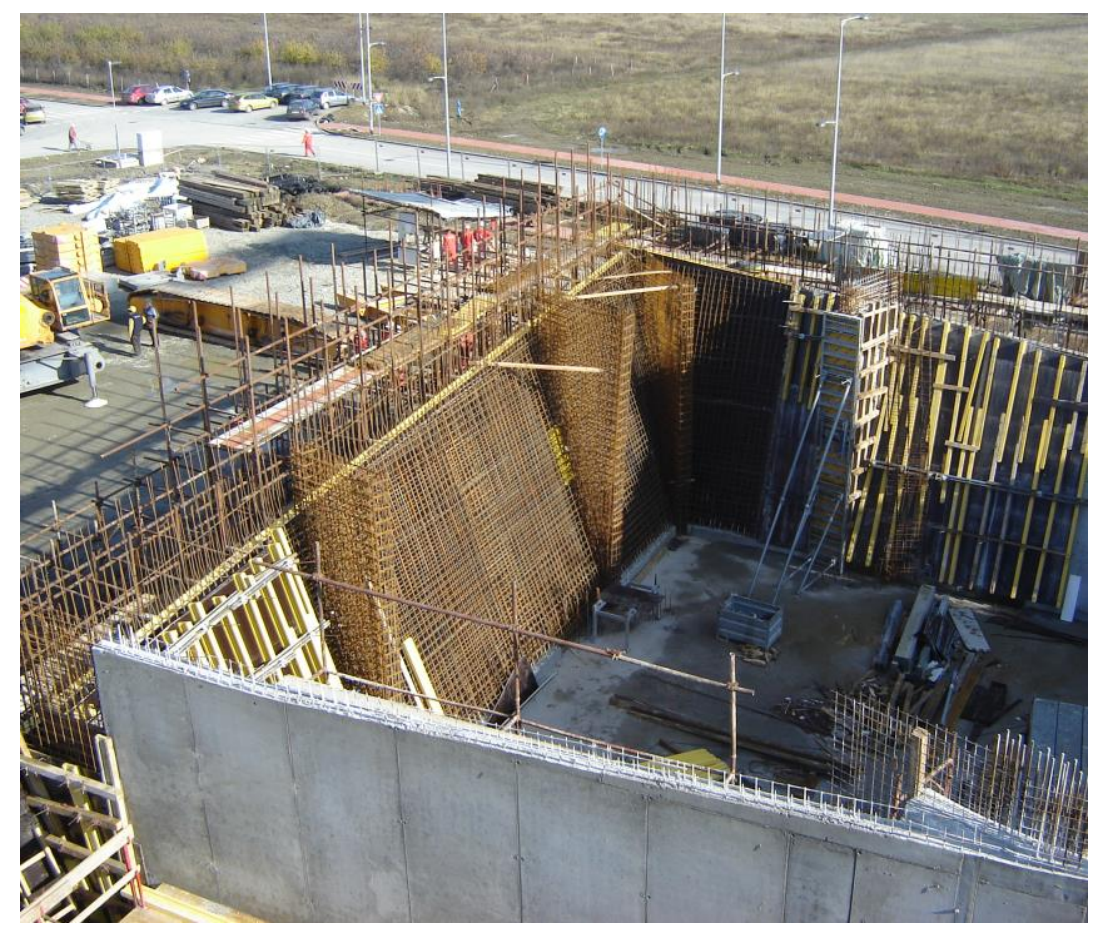

Slika 41 - Izvedba zidova

\section{Globalna kontrola pomaka}

Maksimalni horizontalni pomaci locirani su na svakoj dilataciji posebno (slika 42). Kao mjerodavni, uzeti su pomaci nastali potresnim opterećenjem koji su znatno veći od pomaka zbog vjetrenog opterećenja. Maksimalni pomaci sortirani su u priloženim tablicama. $U$ tablici 5 su prikazani pomaci od anvelope opterećenja: $1.0 \mathrm{~g}+0.5 \mathrm{q} \pm 1.0 \mathrm{~s}$.

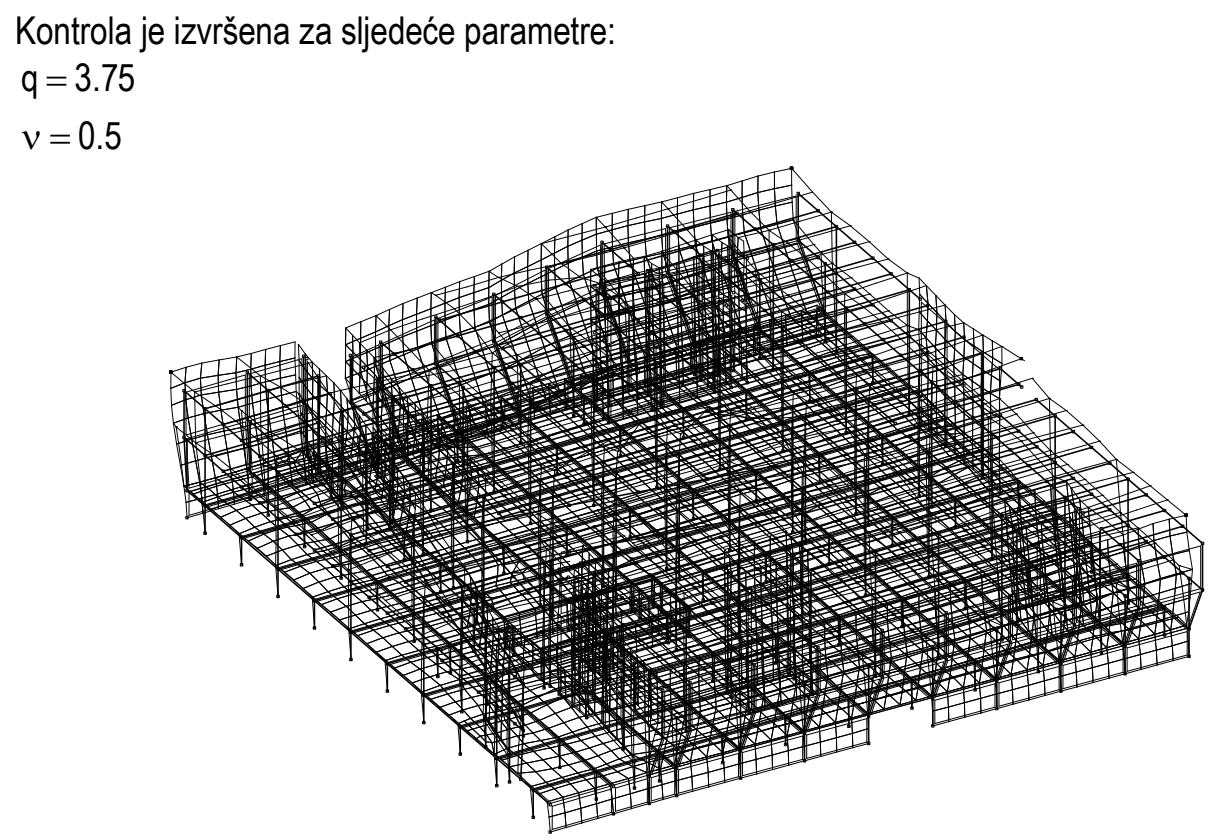

Slika 42 - Pomaci 
Tablica 5 - Pomaci - Dilatacija 2 - Linija Y03-X17

\begin{tabular}{|c|c|c|c|c|c|c|}
\hline Pozicija & $\begin{array}{c}\text { Visina } \\
{[\mathrm{m}]}\end{array}$ & $\begin{array}{c}\text { Pomak kata prema } \\
\text { linearnom } \\
\text { proračunu } \\
\mathrm{d}_{\mathrm{e}}[\mathrm{mm}]\end{array}$ & $\begin{array}{c}\text { Računski pomak } \\
\text { kata } \\
\mathbf{d}_{\mathrm{s}}=\mathrm{q} \cdot \mathrm{d}_{\mathrm{e}}[\mathrm{mm}]\end{array}$ & $\begin{array}{c}\text { Visina kata } \\
\text { h }[\mathrm{m}]\end{array}$ & $\begin{array}{c}\text { Razlika pomaka } \\
\mathbf{d}_{\mathrm{s}} \bullet \mathrm{v}[\mathrm{mm}]\end{array}$ & $\begin{array}{c}\text { Dozvoljeni pomak } \\
0.005 \cdot h \text { [mm] }\end{array}$ \\
\hline 2. kat & 12,5 & 9,149 & 34,31 & 6,0 & 7,72 & 30,0 \\
\hline 1. kat & 6,5 & 5,033 & 18,87 & 6,5 & 7,87 & 32,5 \\
\hline Prizemlje & 0,0 & 0,834 & 3,13 & 3,5 & 1,25 & 17,5 \\
\hline Garaža & $-3,5$ & 0 & 0,00 & & & \\
\hline
\end{tabular}

\section{Literatura}

[1] Poslovno trgovački centar Portanova Osijek - Glavni projekt - Projekt konstrukcija, Aspalathosoft d.o.o., Split, Oznaka projekta 2008-13/2, 2009. (6. knjiga), projektant konstrukcije: Slobodan Blanuša, dipl. ing. građ.

[2] Poslovno trgovački centar Portanova Osijek - Arhitektonski projekt - CHAPMAN TAYLOR ARCHITETTI SRL, Studio d' Architettura, Piazzetta Pattari 1, Milano Italia, autor idejnog rješenja: Alessandro Stroligo dipl.ing.arh.

[3] Poslovno trgovački centar Portanova Osijek - Arhitektonski projekt - STUDIO XXL doo, Ivana Lučića 2a, HR-10000 Zagreb, glavni projektant: Vedran Linke, dipl.ing.arh.

[4] Aspalathos - program za linearnu statičku i modalnu analizu štapnih i pločastih konstrukcija, Uputstvo za upotrebu, Aspalathosoft d.o.o., Split, 2001.

[5] HRN ENV 1991-1 - Eurokod 1: Djelovanja na konstrukcije - Dio 1-1: Opća djelovanja: gustoće, vlastite težine, korisna opterećenja

[6] HRN ENV 1992-1 - Proračun betonskih konstrukcija - Dio 1-1: Opća pravila i pravila za zgrade

[7] HRN ENV 1994-1 - Proračun spregnutih konstrukcija čelik-beton - Dio 1-1: Opća pravila i pravila za zgrade

[8] HRN ENV 1998-1 - Proračun konstrukcija na potres - Dio 1-1: Opća pravila, seizmička djelovanja i pravila za zgrade

[9] Zaninović, K.; Gajić-Čapka, M.; Androić, B.; Džeba, I.; Dujmović, D.: Određivanje karakterističnog opterećenja snijegom, Građevinar, 59, 6, 2001. 